\title{
İLHAMINI KUR'ÂN'DAN ALAN ŞAİR, MEHMED ÂKİF ERSOY
}

Ramazan Şahan*

$\ddot{\mathbf{O} z}$

Mehmed Âkif Ersoy, İstanbul'un Fatih semtinde, medreseye mensûb bir hocanın evinde doğmuş, Kur'ân ruhuyla yoğrulmuş, onun manevi atmosferinde büyümüştür. Halkalı Baytar Mektebi'ni bitirip Adana'da baytarlık yapan Âkif görevi esnasında Kur'ân'1 baştan sona ezberlemiştir. Daha sonra Arapça ve tefsir okuyan Âkif, Kurtuluş Savaşı yıllarında şehir şehir, köy köy gezerek milleti Kur'ân'la, vaaz ve nasihatlerle irşad etmiş, bunun yanında dergilerde ve gazete köşelerinde yazdığı makale ve şiirlerle de halkı bilinçlendirme görevini sürdürmüştür. Bunu yaparken ayetleri şiirlerle açıklamış, böylece vaaz ve uyarılarının daha etkili ve kalıcı olmasını sağlamıştır. Bu şiirlerin çoğu Safahat adlı eserinde toplanmıştır.

Âkif, bazen bir ayet veya bir hadisi başlık yapıp hemen altına bunlardan anladıklarını dizelere dökmüş, bazen bir konuyu izah ederken satır aralarında ayetleri iktibas etmiş, bazen de ayeti lafzen vermese de satır aralarında ayetlerden manevî iktibaslarda bulunmuştur. Bu çalışmada tamamını bir arada görme gayesiyle Âkif'in doğrudan ele aldığı veya manevî iktibasta bulunduğu ayetler ele alınarak onları nasıl yorumladığı incelenmiştir.

Anahtar Kelimeler: Âkif, Kur'ân, Safahat, Şiir, İlham

\section{THE POET WHO HAS TAKEN HIS INSPIRATION FROM THE QURAN MEHMED AKIF ERSOY}

\begin{abstract}
Mehmed Âkif Ersoy was born in a district of Istanbul called Fatih, in a scholar's house who was a member of the madrasah. He has grown with the Quran's spirit and its spiritual atmosphere. He has graduated from the Halkalı Veterinarian School and during his mission as a vet in Adana, he memorized the Quran completely by reading it over and over again. Later on, Âkif learned Arabic and studied Tafseer. During the Independence War, he set out and went from town to town and village to village to guide people with his sermons and advice. Along with his sermons, he has written poems and articles for newspapers and magazines to raise awareness and awaken the people. Mostly, he clarified the Quranic verses with poems and with this he made his sermons and advice a lot more effective and permanent. He gathered all of these poems in a work titled Safahat.
\end{abstract}

Article Types/Makale Türü: Research Article/Araştırma Makalesi

Received/Makale Geliş Tarihi:24/05/2019, Accepted/Kabul Tarihi: 25/08/2019

Doi: 10.26791/sarkiat.569890

* Dr. Öğretim Üyesi, Kocaeli Üniversitesi İlahiyat Fakültesi, Arap Dili ve Belagati ABD Öğretim Üyesi, ramsahan@gmail.com.

ORCID ID: https://orcid.org/0000-0002-7277-4795 
While the poet who has taken his inspiration from the Quran, was explaining the verses with poems, sometimes he took a hadith or a Quranic verse as title and underneath he wrote what he understood from them. Sometimes while he was examining an issue, he gave the Quranic verses between the lines. Sometimes he did not give the verse directly but he referred to Quranic verses and their meanings in a style only an expert can understand. In this study, we will examine the verses that Âkif analyzed directly and referred to, and we will analyze how he interpreted these verses.

Keywords: Akif, Quran, Safahat, Poem, Inspiration

\section{GİRIŞ}

Akif' in dünyasının merkezi Kur'andır. Bunu, kendisi açıkça belirtmiştir. Ona göre yapılacak iş: "Doğrudan doğruya Kur'andan alıp ilhamı / Asrın idrakine söyletmeliyiz İslamı" şeklinde özetlenebilir. Çünkü, Kur'an-1 Kerîm'in prensiplerini uygulayarak, mükemmel ve örnek bir millet olunacağını bu millet tarihinde tecrübe etmiştir.

İstiklal marşımızın şairi Mehmed Âkif Ersoy (1873-1936), yazdığı şiirleriyle Türkçemizin zenginliği kadar dini ve milli meselelere de katkıları olmuş bir Kur'ân şairidir. Bundan dolayı 2011 yılı ülkemizde Mehmed Âkif Ersoy yılı kabul edilmiştir. ${ }^{1}$

Âkif' in en önemli eseri olan "Safahat" çoğunlukla ayetleri, hadisleri, dini ve milli meseleleri konu edinmiştir. Bu çalışmada Ấkif'in Kur'ân'dan aldığ $\breve{l}_{1}$ ilhamla yazdığı şiirler ve ilham aldığı ayetler incelenecektir. Âkif, Safahat'1n Fatih Kürsüsü, Gölgeler ve Hakkın Sesleri gibi bölümlerinde bazen bir ayet veya hadisi konu edinip onu edebî bir üslupla mısralara aktarmış; bazen Süleymaniye Kürsüsü ve Âsım bölümlerinde olduğu gibi dini ve milli bir meseleyi konu edinirken bir ayet ya da hadisle konuyu desteklemiş; bazen de Safahat'in farklı yerlerinde olduğu gibi ayet veya hadisin mealini vermek yerine ona işaret edip atıf yapmış yani bir nevi manvî iktibasta bulunmuştur.

Yeri geldikçe atıfta bulunulacak çalışmalarda görüleceği üzere Akif hakkında oldukça geniş bir literatür mevcuttur. ${ }^{2}$ Ancak bunların kimi Akif'in fikirleini, duygu ve düşüncelerini nesir halinde anlatmış, ${ }^{3}$ kimi onun şiirlerinden tadımlık denecek ölçüde bir iki örnek arz etmiştir. ${ }^{4}$ Kimi de sadece onun bir yönü veya bir şiiri üzerinde yoğunlaşmıştır. ${ }^{5} \mathrm{Bu}$ çalışmanın amacı ise Âkif' in Safahat adlı eserinde doğrudan veya dolaylı olarak Kur'ân'dan aldığı ilhamla yazdığı şiirlerin bütününü arz edebilmektir. Çünkü çoğu kere Âkif’ten bir iki örnek verilerek onun, fikirlerini savunurken yeri

\footnotetext{
1 “T.C. Kültür ve Turizm Bakanlığı”, Mehmet Akif ERSOY Yılı Etkinlikleri, erişim: 6 Ağustos 2019, https://www. aregem.kulturturizm.gov.tr/TR-12228/mehmet-akif-ersoy-yili-etkinlikleri.

${ }^{2}$ Ercan Şen, “Âkif Literatürüne Yeni Bir Katkı: Mehmet Âkif Ersoy’un Kur’ân Anlayışına Dair Yapılan Çalışmalar Üzerine Bibliyografik Bir Deneme”, FSM İlmi Araştırmalar İnsan ve Toplum Bilimleri Dergisi, 6, (2015): 211-221.

${ }^{3}$ Hidayet Aydar, "Bir Kur'ân Müfessiri Olarak Mehmed Âkif", Diyanet İlmi Dergi, $32 / 4$ (1996): 25-50; Musa Bilgiz, “M. Âkif'in Şiir ve Düz Yazılarında Kur'ân'dan Temalar”, EKEV Akademi Dergisi, 15 (2003): 159-178.

${ }^{4}$ Şen, "İctimâî Tefsir Yaklaşımı Açısından Mehmet Âkif Ersoy’un Kur’ân Yorumu”, 163-195; Nurettin Turgay, "Mehmed Akif Ersoy'un Şiirlerinde Kur'an Etkisi ve Din Yoluyla İrşad", Insan ve Toplum Bilimleri Araştırmaları Dergisi, 1/2 (2012): 28-56.

${ }^{5}$ Nurettin Turgay; "Mehmet Akif Ersoy ve Kur'an'ın Birlik Mesajı”, İslâmî Araştırmalar, 21/2 (2010): 119-126; Mahmut Öztürk, "Mehmet Akif'in "Kur'an'a Hitap" Şiiri”, Harran Üniversitesi İlahiyat Fakültesi Dergisi, 24/41 (2019): 73-97.
} 
geldikçe şiirlerinde Kur'ân'a da atıflar yaptığı sanılmaktadır. Oysaki o bütün ilhamını, fikir ve duygu dünyasını Kur'ân'ın aldığı ruhla yoğurmuş, o ruhla şiirlerine hayatiyet kazandırmıştır. Kısacası Âkif sadece bir şair değil, o toplumun dertleriyle birebir ilgilenen Müslüman bir bilim adamı, bir mütefekkirdir. O toplumun problemlerine Kur'ân'ın dışında bir çare aramadığı gibi şiirlerini yazarken de Kur'ân çerçevesi dâhilinde kalmaya gayret etmiştir. Aslında onun şiirlerini ve düşüncelerini tek tek inceleyip dayandığı ayetlerle daha geniş eserler de yazılabilir. Ne var ki böyle sınırları belirli bir makalenin hacmini zorlamamak adına kısaca Akif' in hayatı ve Kur'ân'la olan alakası incelenip mümkün mertebe şiirlerinden örnekler arz edilecektir.

Konunun isminden de anlaşılacağı üzere çalışmada temel alınan kaynak Âkif' in Safahat adlı eseri ve bu eserini yazarken ilham aldığı Kur'ân-1 Kerîm'dir. Mümkün mertebe bu iki kaynağa bağlı kalınacak, bunların dışındaki eserlere konunun izahına katkıda bulnacağı ölçüde müracaat edilecektir.

\section{1. Âkif'in Yetiştiği Ortam}

Âkif'in babas1, Fâtih Medresesi müderrislerinden Mehmed Tâhir Efendi (1826-1888), annesi ise Emine Şerife Hanım (1836-1926)'dır. Babası tahsil için küçük yaşta, Osmanlı ülkesinin Arnavutluk bölgesinin, İpek kazasının Şuşisa köyünden İstanbul'a gelmiştir. Tokat'ta doğan annesi ise aslen Buhâra'lı bir âileye mensuptur. ${ }^{6}$ Böyle bir âilede dünyaya gelen Âkif, dört yıl, dört ay ve dört günlük iken, o günkü Müslüman ailelerin riayet ettikleri geleneğe uyurak Mahalle Mektebi'ne gönderilmiş ve Kur'ân öğrenmeye başlamıştır. $^{7}$

Âkif 8-10 yaşlarında iken hafızlığa başlamış ve iki buçuk aylık kısa bir sürede her cüzden 12 sayfa ezberlemiş; ancak bazı engeller sebebiyle hıfzını tamamlayamamıştır. Baytar Mektebi'ni bitirdikten sonra Adana'daki memuriyeti esnasında hafızlığının geri kalan kısmını tamamlamış, İstanbul'a döndüğünde bir mescitte ezbere mukabele okumuştur. Yine hatimle teravih kıldıracak kadar kuvvetli bir hafız olduğu bilinmektedir. ${ }^{8}$

Âkif, bir yandan Baytarlık mesleğiyle ilgili Fransızca kitapları takip edip diğer yandan da hasta hayvanlarla uğraşırken, kutsal kitabına olan iman ve aşkını asla yitirmemiştir. Yirmi yaşından sonra kendi kendine hafız oluşunu bizzat kendisi şöyle anlatmıştır: "Yüksek tahsili bitirdikten sonra hafız oldum. Fakat ondan evvel Kur'ân'ı okuya okuya gayet pişkin bir hale getirdiğim için zaten hıfz ile aramda uzun bir mesafe yoktu. Az bir müddet içinde Kur'ân'1 ezberleyiverdim.",9

\section{2. Âkif'in Kur'ân Kültürü}

Âkif çocukluğundan itibaren Kur'ân'la meşgul olduğundan Arapça'yı da güzelce öğrenmiştir. ${ }^{10}$ Yayınlanmış ilk şiirinin "Kur'an'a Hitap" olduğu bilinmektedir. İslamiyet, Kur'ân ve Âkif birbirinden ayrılması imkânsız üç isimdir. ${ }^{11}$

\footnotetext{
${ }^{6}$ Mehmed Âkif Ersoy, Safahat, nşr. Ertuğrul Düzdağ (İstanbul: İz Yayıncılık, 2009), 3.

${ }^{7}$ M. Ertuğrul Düzdağ, Mehmed Âkif Hakında Araştırmalar II (İstanbul: İFAV Yayınları, 2006), 79.

${ }^{8}$ Düzdağ, Mehmed Âkif Hakında Araştırmalar II, 87-88; Eşref Edib, Mehmed Âkif Hayatı Eserleri ve

Yetmiş Muharririn Yazıları, haz. Fahrettin Gün, (İstanbul: Beyan Yayınları, 2011), 1: 317.

${ }^{9}$ Ersoy, Safahat, 7; Edib, Mehmed Âkif Hayatı Eserleri, 1: 497.

${ }^{10}$ Edib, Mehmed Âkif Hayatı Eserleri, 1: 230, 335, 415, 547-549.

${ }^{11}$ Düzdağ, Mehmed Âkif Hakında Araştırmalar I, 172.
} 


\section{1. Âkif'in Kur'ân'a İlgisi}

Âkif, Kastamonu'da bir sohbetinde Tefsîr-i Celâleyn'i tam 18 kere hatmettiğini ve 19. hatme devam ettiğini söylemiştir. ${ }^{12} \mathrm{O}$, Kur'ân'ın baş tacı yapıldığı bir evde dünyaya gelmiş, çocukluğundan itibaren hayatı boyunca Kur'ân'la meşgul olmuş, öleceği zaman da Kur'ân dinleyerek ruhunu teslim etmiştir. ${ }^{13}$ Böyle bir kişinin Kur'ân'la meşgul olup ona dair şiirler yazması gayet doğaldır. ${ }^{14}$

Âkif, Osmanlı'dan Cumhuriyet'e geçiş sürecinde kendisine biçilen hayat rolünü ifa eden, Kur'ân ve ilim aşığı Müslüman bir şairdir. O, modernleşme sürecinde hiçbir zaman maziyle bağlarını koparmamış ve koparma taraftarı da olmamıştır. O milletinin mazideki meziyetlerini hep hasretle ve iftiharla yâd etmiştir. ${ }^{15}$ Diğer taraftan Âkif, çağın hızla gelişen şartları içinde bin yıllık eserlerle ve kendini yenileyememiş anlayışlarla toplumun 1slahının mümkün olamayacağını düşünmüştür. ${ }^{16}$

Âkif, yenilenmeyi Kur'ân'dan kopmak olarak değil, bilakis Kur'ân'a dönüş olarak görmüştür. Hatta incelenecek ve örnek alınacak toplum için sahabenin yaşadığı asr-1 saadeti önermiştir. O, Kur'ân'ın sadece lafzının değil, manasının da okunup anlaşılmasını 1srarla vurgulamış ve şöyle demiştir:

'Lafz-1 muhkem yalınız anlaşılan, Kur'an'ın:

Çünkü kaydında değil, hiçbirimiz mananın:

Ya açar Nazm-1 Celîl'in, bakarız yaprağına

Yahud üfler geçeriz bir ölünün toprağına.

İnmemiştir hele Kur'an, bunu hakkıyla bilin

Ne mezarlıkta okunmak, ne de fal bakmak için!"17

Âkif, Kur'ân'dan kopan toplumların gerçek anlamda İslam'la bütünleşemeyeceğini ${ }^{18}$ şöyle belirtmiş̧ir:

“Hani Kur'an'daki rûhun şu heyûlâda izi,

Nasıl İslâm ile birleştiririz kendimizi.?!"19

Âkif batı taklitçiliğine düşmeden iyi örneklerin alınmasını savunurken taassuba düşmeksizin geleneklere bağl1lı̆g savunmuştur. Bu konuda "Eski eski olduğu için

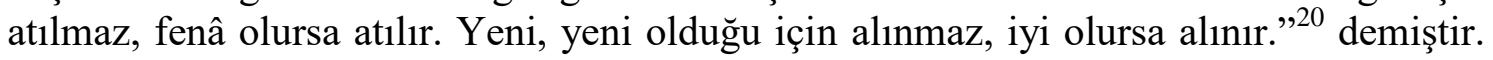

\footnotetext{
${ }^{12}$ Edib, Mehmed Âkif Hayatı Eserleri, 1: 122; Düzdağ, Mehmed Âkif Hakında Araştırmalar I, 77-78.

${ }^{13}$ Ersoy, Safahat, 69. (Giriş).

${ }^{14}$ Düzdağ, Mehmed Âkif Hakında Araştırmalar II, 76-96.

${ }^{15}$ Ersoy, Safahat, 199. (Hakkın Sesleri).

${ }^{16}$ Ersoy, Safahat, 399. (Âsim).

${ }^{17}$ Ersoy, Safahat, 158. (Süleymaniye Kürsüsünde).

18 Âkif, bunları söylerken Tâhâ 20/124-126; Furkan 25/30; Zuhruf 43/36-37 gibi ayetlerden ilham almaktaydi.

${ }^{19}$ Ersoy, Safahat, 390 (Âsim).

${ }^{20}$ Ersoy, Safahat, 83. (Giriş)
} 
Âkif, sırf Kur'ân'dan hareketle diğer şer’î delilleri bir kenara bırakan "Kur'âniyyûn",21 hareketlerinin çağdaş temsilcisi de değildir. Zaten Safahat'ında ayetleri konu başlığı yaptığı gibi yer yer hadisleri de serlevha yaparak şiirlerle açıklamıştır. O hadis konusunda çok titizdir ve sağlamını zayıfından ayırt ederek hadis nakletmeyi savunup şunları söylemiştir:

“Kitâb'1, Sünnet'i, icmâ'ı kaldırıp attık;

Havassı maskara yaptık, avamı aldattık.

Yıkıp şerîati, bambaşka bir binâ kurduk;

Nebî'ye atf ile binlerce herze uydurduk!

O hali buldu ki cür'et: "Yecûzu fi't-tergîb...,"22

Karar-1 erzeli fetva kesildi!... Hem ne garîb,

Hadisi vaz' ediyorken sevab uman bile var!

Sevabı var mı imiş, bir zaman gelir, anlar!

Cihanı titretiyorken nidâ-y1 "Men kezebe..."23

İşitmiyor mu, nedir, bir bakın şu bî-edebe:

Lisân-1 pâk-i Nebî'den yalanlar uyduruyor;

Sıkılmadan da "sevab işledim" deyip duruyor!", 24

Âkif yeterli ilmî donanıma sahip olmaksızın “içtihâd”a kalkışıp Kur’an’dan yorum çıkarmaya çalışanları eleştirmiş, kendini müctehid zanneden bu kişilere karşı hakikati haykırmış, içtihadın şartlarını ve gereklerini şöyle sıralamıştır:

"Bakın ne günlere kaldık: Ya beş, ya altı kopuk,

Yamaklarıyle berâber ki hepsi kılkuyruk,

Utanmadan çıkıyor, içtihada kalkışıyor!

Bu hâle karşı tahammül hakîkaten pek zor.

Düşünmüyor bu kopuklar ki: Müctehid geçinen,

Zamanının olacak muktedâsı irfânen.

Kitab'1, Sünnet'i, îcma'ı sağlam anlıyacak;

Hilafi yoklıyacak, ihtiyacı kolliyacak.

Ne içtihadı yapar, yoksa, bir alay - zimmî

Kadar nasîbe-i fikhîsi olmıyan - ümmî?

\footnotetext{
${ }^{21}$ Geniş bilgi için bk. Şahin Güven, "Kur’âniyyûn Ekolü -Temsilcileri, Tefsirleri ve Tefsirdeki Yöntemi”, Erciyes Üniversitesi Sosyal Bilimler Enstitüsü Dergisi, 11 (2001): 385-408.

${ }^{22}$ Bazılarına göre "İbadete teşvik maksadıyle olursa hadis uydurmak caizdir!"

23 “Kim benim ăgzımdan bile bile bir hadis uydurursa varacă̆ yer cehennemdir." (Buhârî, İlim, 38).

${ }^{24}$ Ersoy, Safahat, 247-248 (Fatih Kürsüsünde).
} 
Kuzum, eşek nalı yapsan: Bir usta çingenenin

Yanında uğraşacaksın, başında mengenenin." 25

Bütün bunlar Âkif'in bilinen anlamda bir reformist olmadığını göstermektedir. O İslam adına ne yapılması gerekiyorsa o yolda doğru bildiklerini savunmuş, kimsenin hatrına söz söylememiştir. ${ }^{26}$

Eserlerinde Kur'ân, İslam, din ve ahlak temalarını işleyen Âkif, konuşma, yazı ve şiirlerinde Kur'ân'1 açıklama, yorumlama ve yaşama gayreti içinde olmuştur. ${ }^{27}$ Çalışmamızda Âkif' in diğer eserlerinden ziyade şiirlerinde Kur'ân'a bakış açısı ve Kur'ân'1 yorumlama biçimi ele alınmış, mümkün olduğunca okuyucunun, Âkif'in Kur'ân'dan mülhem bütün şiirlerini ve hangi şiirinin hangi ayetten ilham alınarak yazıldığını öğrenmesi hedeflenmiştir.

\section{2. Âkif'in Kullandığı Kur'ânî Kavramlar}

Âkif, Kur'ân'a dair pek çok kavramı kullanmıştır. 'Kur'ân-1 Kerîm, vahy-i İlâhî, tilâvet, lafz-1 muhkem, ruh-1 edyân, hikmet-i Kur’ân, Nazm-1 Celîl, Fâtiha, Tebâreke, Besmele, Sûre-i Nûr, Sûre-i ve'l-'Asr, âyât" gibi kavramlar bunlardan bazılarıdır. ${ }^{28}$

\section{3. Âkif'in Kur'ân'ı Niteleyen Manzûmeleri}

Âkif bazı şiirlerinde doğrudan Kur'ân'ı konu edinmiş ve bir şiirinde Kur'ân'a hitap ederek şunları yazmıştır:

“Ey meş’al-i hikmet-i İlâhi!

Ey mecma'-1 feyz-i bî-tenâhî!

Furkan ki kitâb-1 Mustafâ'dır,

Bir mu'cize-i Hudâ-nümâdır.

Ahmed ki nebiyy-i bî-gümandır,

Kur'ân ile feyz-yâb-1 şandir.

Fe'tû... diyerek Resûl-i Ekrem, ${ }^{29}$

Eylerdi muannidini mülzem."30

$\mathrm{Bu}$ uzunca şiir başlı başına bir araştırma konusudur. ${ }^{31}$ Âkif verdiğimiz kısmında Kur'ân'ın ezelî bir muize olduğunu ve defalarca meydan okumasına karşın inatçı kâfirlerin onun benzerini getiremediklerini vurgulamıştır.

\footnotetext{
${ }^{25}$ Ersoy, Safahat, 250-251 (Âsım).

${ }^{26}$ Düzdağ, Mehmed Âkif Hakında Araştırmalar II, 116-121; Ersoy, Safahat, 86-87 (Giriş).

${ }^{27}$ Düzdağ, Mehmed Âkif Hakında Araştırmalar II, 76-96.

${ }^{28}$ Bu kavramlar için bk. Ersoy, Safahat, 673-704 (İndeksler).

${ }^{29}$ Kur'an " "فَّ /fe'tû́!/Haydi getirin..." şeklinde defalarca meydan okumuş yani tehaddî etmiştir. Bazen tamamının benzerini getirin (Tûr 52/33-34; Kasas 28/49-50; Enfal 8/31-32) denilmiş; bazen on suresinin benzerini uydurun (Hûd 11/13-14) denilmiş; bazen tek bir suresinin benzerini getirin (Bakara 2/23-24; Yunus 10/38.) denilmiş; bazen de insanlar ve cinler hepiniz toplanın, Kur'ân'ın benzerini getirin denilmiş (İsra 17/88) fakat cevap veren olmamıştır.

${ }^{30}$ Ersoy, Safahat, 506-507.
} 


\section{3. Âkif'in Konu Başlı̆̆ı Yaptığı Ayetler}

Âkif, bazen ayetleri bazen de hadisleri konu başlı̆̆ı yapıp şiirleriyle açıklamıştır. ${ }^{32}$ Bunlardan bazıları şu şekildedir:

\section{1. İnanç Esaslarıyla İlgili Ayetler}

\subsection{1. İman-Tevekkül ve Çalışmak}

Kur'an'da Allah'ın gücü, kudreti ve yarattıklarına müdahalesi şöyle anlatılmıştır: "De ki; 'Ey mülkün sahibi olan Allah'ım! Sen mülkü dilediğine verirsin; sen mülkü dilediğinin elinden alırsın; sen dilediğini aziz edersin; sen dilediğini zelil edersin; hayır yalnız senin elindedir; sen, hiç şüphe yok ki, her şeye kadirsin." 33

Ayetteki "mülk" kelimesi tefsirlerde genellikle "Peygamberlik, kudret, yönetme gücü, zafer, egemenlik, ilim, servet, itibar, akıl, sağlık gibi her türlü maddî ve manevî imkân" anlamlarıyla açıklanmıştır. ${ }^{34}$ Bütün bu nimet ve imkânları dilediği bir topluma ihsan edip onları yüceltebileceği gibi hakkını eda edemedikleri zaman o toplumun elinden alıp onları hor hakîr de kılabilir. Bu ayetler ilâhî irade karşısında kulun iradesinin etki ve değerini de belirlemektedir. ${ }^{35}$ Konuya dair ayetler ve ilgili hadisler birlikte değerlendirildiğinde inanıp gereği ile amel edenlerin yükselebileceği; gerçeği gördüğü halde inkârcılıkta direnip bunu ideoloji haline getirenlerin de alçalabileceği anlaşılır. Bir toplum kendini değiştirmedikçe de Allah o toplumla ilgili hükmünü değiştirmez. ${ }^{36} \mathrm{Bu}$ yükselme ve alçalmalarda İlâhî iradenin yanında kulun iradesinin de rolü vardır. Yine imkânsız gibi görülen nice başarılar Allah'ın lütuf ve kudretiyle gerçekleşebilir. ${ }^{37}$

Âkif, ilâhî irade karşısında kulun irade ve gayretinin yerini şöyle anlatmıştır:

"İlâhî, emrinin âvâre bir mahkûmudur âlem;

Meşiyyet sende, her şey sende... Hiçbir şey değil âdem!

Fakat, hâlâ vücûd isbât eder, kendince, hey sersem!

Bugün, üç beş karış toprakta varlıktan vururken dem;

Yarın, toprak kesilmiş varlığından fişkırır mâtem!

İlâhî, “Malike'l-mülk’üm” diyorsun... Doğru, âmennâ.

Hakîkî bir tâsârruf var mıdır insan için? Aslâ!

\footnotetext{
${ }^{31} \mathrm{Bu}$ konuda geniş bilgi için bk. Mahmut Öztürk, "Mehmet Akif'in “Kur'an’a Hitap” Şiiri”, Harran Üniversitesi İlahiyat Fakültesi Dergisi, 24/41 (2019): 73-97.

${ }^{32}$ Mehmed Âkif Ersoy, Tefsîr Yazıları ve Vaazlar, nşr. Ertuğrul Düzdağ, (Ankara: Diyanet İşleri Başkanlığı Yayınları, 2012), 137-176.

33 Âl-i İmran 3/26.

34 Ebû'l-Kâsım Mahmûd b. Ömer b. Ahmed Zemahşerî, el-Keşşâf an hakâîku gavâmidi't-tenzîl ve 'uyûni'l-akâvîl fî̀ vucûhi't-te’vîl (Beyrut: Dâru'l-Kütübi'l-Arabî, 1407/1986), 1: 182.

${ }^{35}$ Fahruddin er-Râzi, Mefâtîhu'l-ġayb, (Beyrut: Dâru İhyâi Türâsi'l-Arabi, 1420/1999), 8: 6-7.

${ }^{36}$ Enfâl 8/53; Ra'd 13/11.

37 Zemahşerî, Keşşâf, 1: 183; Ebû Muhammed Abdulahk b. Ġâlib b. Abdurrahman İbn 'Atıyye, elMuharraru'l-vecîz fî tefsîri'l-kitâbi'l-'azîz, thk. Abdusselam b. Abdişşâfî Muhammed (Beyrut: Dâru'lKütübi'l-'İlmiyye, 1422/2002), 1: 417; Karaman, Hayrettin- Çağrıcı, Mustafa- Dönmez, İbrahim KafiGümüş, Sadrettin, Kur'ân Yolu (Ankara: DİB Yayınları, 2004), 1: 387-389.
} 
Eğer almışsa bir millet, edip bir mülkü istilâ;

Eğer vermişse bir millet bütün bir mülkü bî-pervâ;

Alan sensin, veren sensin, senin hükmündedir dünyâ.

Âkif yukarıdaki mısralarda ilâhî irade ve kudretin mahiyetini arz ettikten sonra naz makamında Allah'a niyaz ederek neden kâfirler karşısında Müslümanların yardımsız bırakıldığını dile getirip ardından yine kendi kendini susturmaya çalışmış, insanın kendi el emeğinden başka bir şey elde edemeyeceğini şöyle vurgulamıştır:

“Sus ey divâne! Durmaz kâinâtın seyr-i mu’tâdı.

Ne sandın? Fıtratın ahkâmı hiç dinler mi feryâdı?

Bugün, sen kendi kendinden ümîd et ancak imdâdı;

Evet, sen kendi ikdamınla kaldır git de bîdâdı.

Cihân kânûn-i sa’yin, bak, nasıl bir hisle münkâdı!

Ne yaptın? "Leyse li'l-insâni illa ma-se'a” vardı!...”38

Âkif burada bir taraftan mülkün gerçek sahibi olan Allah'ın güç ve kudretine dikkat çekerken diğer yandan da kader ve tevekülün doğru anlaşılması için son misrada "İnsan için kendi çalışmasından başka bir şey yoktur" ${ }^{39}$ ayetini iktibas edip suçu kadere yüklemenin yanlış olduğunu belirterek ayeti ayetle tefsîr etmiştir. ${ }^{40}$

“Âkif’te Beşerî İhtiyâr ve Kader Akîdesi” diye bir başlık açmış olan Eşref Edîp, Âkif’in bu konudaki itidale uygun görüşlerini anlatarak onun, ilâhî iradenin her şeyin üstünde olduğunu kabul etmekle birlikte insana verilen hürriyet ve bunun karşılığında istenilen mes'ûliyyeti asla göz ardı etmediğini belirtmiştir. Kader konusunda kendisini teselli ve takviye için Eşref Edîp, Âkif'e şunu nakletmiştir:

- Meşhur Einstein'ın “Dünyayı nasıl görüyorum?” adındaki eserinde şöyle bir sözü vardır. "Felsefi manasıyla hürriyete inanmiyorum" Schopenhauer'in şu sözü gençliğimden beri üzerimde derin bir te'sîr bırakmıştır: "Şüphesiz bir insan istediğini yapar, fakat her istediğini de isteyemez." Schopenhauer'in, Einstein'1 da düşündüren bu sözüne göre insan yapmakta hür sayılsa bile istemekte hür değil. Yapmak ise istemeğe bağl1." dedim. Bunun üzerine Üstad hemen "Allah dilemedikçe siz dileyemezsiniz..."41 ayetini okuyarak sözümü bağlayıverdi. Âkif’in yazılarında İslamî rasyonalizmin izleri bulunmakla beraber bu durum onun kader inancına da bağlı kaldığını göstermektedir."42

\subsubsection{Gerçek Mütevekkil Müminler}

Bir ayette Allah'a tevekkül eden Müslümanlar şöyle övülmüştür: 'Şu mü’minlere Allah katında büyük bir ecir vardır: Birtakım kimseler kendilerine 'Düşmanlarınız sizin için

\footnotetext{
${ }^{38}$ Ersoy, Safahat, 182-184. (Hakkın Sesleri)

${ }^{39} \mathrm{Necm}$ 53/39.

${ }^{40}$ Aydar, "Bir Kur'ân Müfessiri Olarak Mehmed Âkif”, 27-40. Âkif, bu şiiri ve ilgili ayetleri Balkan savaşları esnasında Fatih camiinde vaaz ederken okumuş, cemaati hem ağlatmış hem düşündürmüştür. Edib, Mehmed Âkif Hayatı Eserleri, 1: 81-84.

${ }^{41}$ İnsan 76/30; Tekvir 81/29.

${ }^{42}$ Edib, Mehmed Âkif Hayatı Eserleri, 1: 523-525.
} 
kuvvetlerini topladılar; onlardan korkmalısınız' dedikleri zaman bu haber îmanlarını artırır da: 'Allah bize yeter, o ne güzel muhafizdır!' derler."43

Bu ayetler Uhud Savaşı'nın ardından, o çetin şartlarda, yaralı olmalarına rağmen Hz. Peygamber'in çağrısına uyarak kendilerinden oldukça kalabalık ve güçlü olan düşmanı takip eden müminler hakkında inmiştir. ${ }^{44}$

Kureyş ordusu kumandanı Ebû Süfyân, Müslümanların üzerine tekrar saldırıp onları imha etmek için plan hazırlarken müslümanların kalabalık bir kuvvet halinde Hamrâü'lEsed denilen yere geldiklerini haber alınca, planından vazgeçmiştir. Bu esnada oradan geçmekte olan bir kervanın adamlarına, "Muhammed'e rastlarsanız ona, kendilerini toptan yok edeceğimizi söyleyiniz" diyerek müslümanları korkutmak istemiştir. Bu söz Hz. Peygamberle birlikte Müslümanlara ulaştığında onlar, "Hasbünallahü ve ni'me'lvekil /Allah bize yeter, O ne güzel vekildir!" demişlerdir. İşte bu olay üzerine inen bu ayetler her türlü olumsuzluğa rağmen müslümanların Allah ve Resûlü'ne olan imanlarını, güvenlerini ve kararlılıklarını göstermiştir. ${ }^{45}$

Âkif, işte korkusuzca davranan müminleri överek bu konuda şunları söylemiştir:

“Şehâmet dîni, gayret dîni ancak Müslümanlık’tır;

Hakîkî Müslümanlık en büyük bir kahramanlıktır.

Cebânet, meskenet, dünyâda, sığmaz rûh-i İslâm'a...

Kitabullah'1 işhad eyledim - gördün ya - da'vâma.

Görürsün, hissedersin varsa vicdanınla îmânın:

Ne müdhiş bir hamaset çarpıyor göğsünde Kur'an'ın!

O îmandan velev pek az nasîb olsaydı millette,

Şu üç yüz elli milyon halkı görmezdin bu zillette!

O îman ittihad isterdi bizden, vahdet isterdi...:

Nasıl "bünyân-1 mersûs" olmamız lâzımsa gösterdi. ${ }^{46}$

O îman kuvvet ihzariyle emretmişti... Lâkin, biz

'Tevekkelnâ' deyip yattık da kaldık böyle en aciz! ${ }^{47}$

'Hakîkî Müslümanlık en büyük bir kahramanlıktır'

Demiştim... îşte da’vam onların hakkında sadıktır."

\footnotetext{
43 Âl-i İmran 3/173.

${ }^{44}$ Muhammed Hamdi Yazır Elmalılı, Hak Dini Kur'ân Dili (İstanbul: Eser Neşriyat, 1979), 2: 1231.

45 Ebû'l-Fidâ İsmail b. Ömer İbn Kesîr, Tefsîru'l-Kur'âni'l-Azîm, thk. Sâmî b. Muhammed Selâme (Riyâd: Dâru Taybe, 1420/1999), 2:168-169. Bir rivayete göre ateşe atıldığı zaman Hz. İbrahim de bu sözü söylemiştir. Bilgi için bk. Buhârî, Tefsîr, Sûretü Âl-i İmran, 13.

46 Âkif burada Saff 61/4. ayetindeki "bünyân-1 mersûs" ifadesine dikkat çekmiştir.

${ }^{47}$ Tevekkelnâ: Allah'a tevekkül edip ona güvendik, ona bağlandık.

${ }^{48}$ Ersoy, Safahat, 289-290 (Hatıralar).
} 
Âkif, hakîkî müslümanlğın en büyük bir kahramanlık olduğunu iddia ediyor, bunu ispatlamak için de Kur'ân'dan ayetler getiriyor. Kur'ân'dan kopan Müslümanların ise hiçbir emek ve gayret göstermeden boşu boşuna tevekkül ettiklerini açıklamaktadır.

\subsubsection{Dünya Ahiret Dengesi}

Bir ayette ahretteki felahın ve hüsranın bu dünya hayatındaki tavır ve davranışlara bağlı olduğu şu şekilde anlatılmıştır: "Kimin bu dünyâda gözü kapalı ise ahirette de kapalı, hatta oradaki şaşkınlığı daha ziyadedir."49

$\mathrm{Bu}$ ayette insana sunulan üstün lütufların asıl sahibini göremeyen, varlık ve olayların arkasındaki yaratıcı güçten habersiz olarak yaşayan basiret yoksunu inkârcıların âhiretteki durumunun daha kötü olacağı bildirilmiştir. Şu halde oradaki körlük, cennetin yolunu göremeyip ondan mahrum kalmaktan kinâyedir. ${ }^{50}$ Dünya âhiretin tarlasıdır. Bu dünyada hakikati görüp tanıyan ve bu sayede doğru imana ulaşan, iyi ve güzel ameller işleyenler âhirette bunun karşılığını eksiksiz bulacaklardır. ${ }^{51}$ Âkif bu konuda şunları söylemiştir:

"Nihayet neyse idrak ettiğin şey ömr-i fâniden;

Onun bir aynıdır mutlak nasibin ömr-i sâniden.

Hatadır ahiretten beklemek dünyâda her hayrı:

Öbür dünyâ bu dünyâdan değil, hem hiç değil, ayrı.

Eğer maksûdu ancak ahiret olsaydı Yezdân'ın;

Ne hikmet vardı ibdaı'nda hiç yoktan bu dünyânın?

"Elest"in arkasından gelmesin Cennet, Cehennem de, ${ }^{52}$

Neden ervâha tekrar imtihan olsun bu alemde?!"53

Kim bu dünyada ne ekerse ahirette onu biçecektir. Âkif bu şiirleriyle aynı zamanda "Dünya ahiretin tarlasıdır" 54 sözünü de izah etmiştir.

\subsection{Ahlakî-İçtimâî Konulara Dair Ayetler}

\subsubsection{Allah Korkusu ve Ahlakın Önemi}

Kur'ân'da, şöyle emir verilmiştir: “Ey iman edenler, Allah’tan, nasıl korkmak lazımsa öylece korkunuz ve ancak Müslümanlar olarak can veriniz." 55

\footnotetext{
${ }^{49}$ İsra $17 / 72$.

${ }^{50}$ Râzî, Mefâtîh, 21: 19.

51 İsrâ 17/71. Geniş bilgi için bkz.: Heyet, Kur'an Yolu, 3: 437-438.

${ }^{52}$ Araf 7/172. ayetteki "Elest" bezmine telmih vardır.

${ }^{53}$ Ersoy, Safahat, 285-286 (Hatıralar).

${ }^{54}$ Şûrâ 42/19-20. vb. ayetlerin manasından mülhem olan bu söz için bk. Nâsıruddin Abdullah b. Ömer elBeyzâvî, Envâru't-tenzîl ve esrâru't-te'vîl, thk. Muhammed Abdurrahman el-Mar'aşlî, (Beyrut: Dâru İhyâi't-Turâsi'l-Arabî, 1418/1998), 5:79; Ebu'l-Fida İsmail b. Muhammed Aclûnî, Keş̧ü'l-hafâ ve muzîlu'l-ilbâs ammâ iştehere mine'l-ehâdîs ala elsineti'n-nâs, thk. Abdulhamîd b. Ahmed b. Yusuf b. Hendâvî, (Beyrut: el-Mektebetü'l-'Asriyye, 1420/2000), 1:471.

55 Âl-i Îmran 3/102.
} 
"Allah'a karşı gereği gibi saygılı olun" diye çevrilebilecek olan kısımdaki "takva" kavramı dinî bir terim olarak "kişinin, kendisini günahkâr kılacak şeylerden koruması" veya "insanın ibadet ve güzel ișler yaparak Allah'ın azabından korunması" șeklinde tarif edilmiştir. ${ }^{56}$ Nitekim Abdullah b. Mes'ûd (ö. 32/652-53) takvayı "Allah’a âsi olmayıp itaat etmek, nankör olmayıp şükretmek ve O'nu unutmaksızın hep hatırda tutmak" şeklinde açıklamıştır. ${ }^{57}$

$\mathrm{Bu}$ ayet (3/110) indiğinde ashâb, Allah'a karşı gereği gibi saygılı olma konusunda endişeye kapılmış, bir yandan hiç kimsenin bunu hakkıyla yerine getiremeyeceğini söyleyip bir yandan da kendilerini aşırı derecede ibadete vermiştiler. Bunun üzerine, "Gücünüz yettiğince Allah'a saygısızlıktan sakının..."58 mealindeki ayet inmiş ve Allah'tan hakkıyla korkmanın, "kişinin gücü yettiği kadar Allah'ın emir ve yasaklarını yerine getirmesi" anlamına geldiği izah edilmiştir. ${ }^{59}$

Kur'an'da pek çok ayette Allah'a karşı saygının (takvâ) önemi vurgulanmış, ${ }^{60}$ hadislerde de takvanın kalpte ve ahlakın Allah korkusuna bağlı olduğu vurgulanmıştır. ${ }^{61}$

Âkif de yukarıdaki ayeti açıklarken şunları yazmıştır:

"Ne irfandır veren ahlâka yükseklik, ne vicdandır;

Fazilet hissi insanlarda Allah korkusundandir.

Yüreklerden çekilmiş farz edilsin havf-1 Yezdân'ın...

Ne irfanın kalır te'sîri kat'iyyen, ne vicdânın.

Oyuncak sanmayın! Ahlâk-1 millî, rûh-i millîdir;

Onun iflası en korkunç ölümdür: Mevt-i küllidir.",62

Âkif ahlakî sorumluluk sahibi olmayanları gerçek Müslüman olarak görmeyip "Kim Müslümanların derdini kendine mal etmezse onlardan değildir." ${ }^{63}$ hadisini verdikten sonra da şunları söylemiştir:

"Müslümanlık nerde! Bizden geçmiş insanlık bile...

Âlem aldatmaksa maksad, aldanan yok, nafile!

Kaç hakiki Müslüman gördümse, hep makberdedir;

Müslümanlık, bilmem amma, galiba göklerdedir.",64

\subsubsection{Islahatçı Olmak}

\footnotetext{
${ }^{56}$ Râğıb el-İsfehânî, el-Mufredât fî garîbi'l-Kur ân, (İstanbul: Kahraman Yayınları, 1986), 823.

57 Ebû Abdullah İbnu'l-Beyyi' Muhammed Hakim en-Nîsâbûrî, el-Mustedrek 'ale's-Sahîhayn, thk. Mustafa Abdülkadir Ata (Beyrut: Dârü'l-Kütübi’l-İlmiyye, 1411/1990), 2: 294.

58 Tegâbün 64/16.

${ }^{59}$ Zemahşerî, el-Keşşâf, 1: 394; İbn Kesîr, Tefsîru'l-Kur âni'l-Azîm, 8:140-141.

${ }^{60}$ Bakara 2/194, 197; Âl-İ İmrân 3/76; A'râf, 7/26; Ra'd 13/35; Hucurât 49/13; Câsiye 45/19, vs.

${ }^{61}$ Buhari, İman 39, Büyû' 2; Müslim, Müsâkat 107, Birr, 32.

${ }^{62}$ Ersoy, Safahat, 281 (Hatıralar).

${ }^{63}$ Zeynuddin Muhammed Abdürrauf b. Tacilarifin b. Ali Munavi, Feyzu'l-kadîr şerhi'l-câmi's-sagî̀r, thk. Hamdî ed-Demirdaş Muhammed (Mekke: Mektebetü Nizâr Mustafa el-Bâz, 1418/1998), 6: 67.

${ }^{64}$ Ersoy, Safahat, 283.
} 
Her insan kendi aklının üstün ve gittiği yolun doğru olduğunu ispatlamaya çalışır. Müminin delili ve bilgi kaynağı vahiy (Kur'ân ve hadislerdeki bilgiler), akıl ve duyu organlarıdır. ${ }^{65}$ İnanmayanlar yalnızca beşerî bilgi kaynaklarıyla yetinip birçok konuda hataya düşer, yanlış yollara saparlar ve yaptıklarının doğru olduğunu savunurlar. ${ }^{66}$ Hak dine inanmayanlar, akıl üstü konularda yanıldıklarını çoğu defa anlamazlar. ${ }^{67}$

Münafıklar hakkında Allah şöyle buyurmuştur: “Onlara: 'yeryüzünde fesat çıkarmayın' denildiği zaman, 'Biz ıslahtan başka bir şey yapmıyoruz' derler. İyi bil ki: Onlar, işte asıl müfsid onlardır, lâkin farkında değillerdir." "68 Âkif hem toplumu yanlışa sürükleyen hem de hala kendilerini ıslahatçı gibi gösteren bu tür ikiyüzlü insanlar hakkında şunları söylemiştir:

"Bir yığıın kundakçıdan yangın görenler milleti,

Şimdi inmiş zanneder mutlak şu müdhiş ayeti!

"Bir kızarmaz çehre bulmuşsun ya, ey canî, bürün;

Hem bütün dünyâyı ifsad eyle, hem muslih görün!

Düşme ey âvâre millet, bunların hızlânına;

Vâkıfız biz hepsinin pek muhtâsâr irfânına:

Şark’a bakmaz, Garb’1 bilmez, görgüden yok payesi;

Bir kızarmaz yüz, yaşarmaz göz bütün sermayesi!"69

Âkif bu şiiriyle ikiyüzlü münafikların gerçek mahiyetini anlatmış, gerçek müminlerin bunlara kanmaması için dikkatli olmaları hususunda ikaz etmiştir.

\subsubsection{Helâkimizin Sebebi Kendi Yaptıklarımız}

Kur'ân'da Hz. Salih'in gönderildiği Semûd kavminin helak oluşları anlatılmış, nihayetinde de viraneye dönen yurtlarının sebebinin kendi haksızlıkları olduğu belirtilmiştir. ${ }^{70}$ Ancak bu olayın sırf tarihi bir kıssa olmayıp ibret alınması gereken bir hâdise olduğu şöyle vurgulanmıştır: "İște sana, onların kendi yolsuzlukları yüzünden, ıpıssız kalan yurtları!...,71

Âkif bu tarihi olayı çağımızdaki Müslümanların perişan haline uyarlamış, onların başlarına gelen felaketlerin de kendi yaptıkları davranışlar sonucu meydana geldiğini şöyle vurgulamıştır:

“Geçenler varsa İslâm'ın şu çiğnenmiş diyarından;

Şu yüz binlerce yurdun kanlı, zâirsiz mezarından;

${ }^{65}$ Bilginin kaynağı üçtür: Haber-i sâdık/vahiy, akıl ve duyu organları. Geniş bilgi için bk. Harun Çağlayan, Kelâm'da Bilgi Kaynakları, (Doktora Tezi, Ankara Üniversitesi, 2009), $22-97$.

${ }^{66}$ Zuhruf 36-37.

${ }^{67}$ Heyet, Kur'an Yolu, 1: 26.

${ }^{68}$ Bakara 2/11-12.

${ }^{69}$ Ersoy, Safahat, 201-203 (Hakkın Sesleri).

${ }^{70}$ Semûd kavminin helâk oluş sebepleri ve ibretli kıssaları hakkında geniş bilgi için bk. Fadıl Hasan Abbas, Kașașu'l-Kur'âni'l-Kerîm (Amman: Dâru'n-Nefâis, 1430/2010), 229-249.

${ }^{71} \mathrm{Neml} 27 / 52$. 
Yürekler parçalar bir nevha dinler reh-güzarından!

Bu mâtem, kim bilir, kaç münkesir kalbin gubarından

Hurûş etmekte, son ümmîdinin son inkisarından?”

"Bu 1ssız âşiyânlar bir zaman candan muazzezdi;

$\mathrm{Bu}$ damlar böyle baykuş seslerinden çın çın ötmezdi;

Şu kurbağlar seken vadide, ceylanlar koşup gezdi;

Şu coşmuş, ağlayan ırmak ne handân gölgeler sezdi;

Bütün mâzîyi bir tufan, fakat hep boğdu, hep ezdi!"’72

Âkif, bu şiirin devamında da toplumun yıkılışına sebep olan ve dinden yüz çevirenlere lanetler okuyarak İslam âleminin yalnızlığına ve kimsesizliğine ağlamak istemiştir.

\subsubsection{Belanın Umumî Olup Hususî Olmayışı}

Peygamberimiz şöyle buyurmuşlardır: “Allah bir kavme azap indirdi mi, o azab, kavmin içinde bulunan herkese isabet eder. Sonra, herkes niyetlerine ve amellerine göre diriltilir." "73 İşte böyle bir toplumla aynı akıbeti paylaşmamak için Müslüman, içinde bulunduğu toplumda kötülükleri yasaklayıp güzel şeyleri emreder. ${ }^{74}$ Eğer toplumu düzeltme şansı ve hayat hakkı kalmadıysa, aynı akıbeti hak etmemek için o toplumu terk eder. ${ }^{75} \mathrm{Bu}$ konuda bir ayette "İçimizdeki beyinsizlerin işledikleri yüzünden, bizi helâk eder misin, Allah'1m..., "76 buyrulmuştur.

Âkif, yukarıdaki ayeti serdettikten sonra Rabbine serzenişle şu mısraları yazmıştır:

"Yâ Rab, bu uğursuz gecenin yok mu sabâhı?

Mahşerde mi bîçârelerin, yoksa felâhı!

La-yüs'el'e binlerce suâl olsa da kurban;

İnsân bu muammalara dehşetle nigeh-bân!

Yetmez mi musab olduğumuz bunca devahî?

A ğzım kurusun... Yok musun ey adl-i İlâhî!"77

Bu şiirde Âkif “La-yüs'el” ifadesiyle "O, yaptıklarından sorumlu değildir, O'na sorgu yapılamaz..." (Enbiyâ 21/23) ayetinden de manevî iktibasta bulunmuştur. Her ne kadar hikmetinden suâl olunmazsa da insane yaratılışı gereği bazı şeyleri sormadan edemez. Âkif ayeti ayetle tefsîr ederken nasıl bir kültüre hakim olduğunu da göstermektedir.

\subsubsection{Bilenlerle Bilmeyenlerin Durumu}

\footnotetext{
${ }^{72}$ Ersoy, Safahat, 185 (Hakkın Sesleri).

${ }^{73}$ Buhârî, Fiten. 19; Müslim, Sifatu'l-Cenne, 84.

${ }^{74}$ Enfal 8/33; Hud 11/116-117; Kasas 28/59;

${ }^{75}$ Nisa 4/140; En'am 6/68; Enfal 6/25.

${ }^{76}$ A'raf $7 / 155$.

${ }^{77}$ Ersoy, Safahat, 195 (Hakkın Sesleri). Âynı konuyu anlatan bir başka şiir için bk. Ersoy, Safahat, 591.
} 
Kur'ân'da bilenlerle bilmeyenlerin aynı olmayacağı şöyle ifade edilmiştir: "Hiç bilenlerle bilmeyenler bir olur mu?...,"78 Âkif, bu ayeti serdettikten sonra şu misraları yazmıştır:

“Olmaz yâ ... Tabî’̂̂... Biri insan, biri hayvan!

Öyleyse, 'cehâlet' denilen yüz karasından,

Kurtulmaya azmetmeli baştan başa millet.

Kâfi mi değil yoksa, bu son ders-i felâket?"79

Bir baksana: Gökler uyanık, yer uyanıktır;

Dünyâ uyanıkken uyumak maskaralıktır!

Ey millet, uyan! Cehline kurban gidiyorsun!

İslâm'1 da 'batsın!' diye tutmuş, yediyorsun!

Lâkin, ne demek bizleri Allah ile iskât?

Allah'tan utanmak da olur ilm ile... Heyhât!"

Âkif, şiirinin giriş kısmında insanla hayvanın farkının ilim olduğunu vurguladığı gibi gerçek manada Allah'tan kormanın da ilimle olacağını belirterek "Kulları içinden ancak âlimler, Allah'a (gereğince) saygı duyar" (Fatır 35/28) ayetine işaret etmiştir. Âkif, bir başka şiirinde de ilmin önemine değinen ayetlerin manasını şöyle özetlemiştir:

"Fakat câhille âlim büsbütün nisbet kabul etmez:

O bir kördür, bu lâkin doğru yoldan hiç udûl etmez.

“Diyor Kur'an: “Bilenler, bilmiyenler bir değil... Heyhat

Nasıl yeksan olur zulmetle nur, ahyâ ile emvât!",81

Âkif bu ifadeleriyle "Körle gören, karanlıkla aydınlık, gölge ile sıcak bir olmaz. Dirilerle ölüler de bir olmaz..."82 ayetine vurgu yapmıştır.

Âkif, elde edilecek ilmin Kur'ân'ın verilerine göre olması gerektiğini vurgulamış ve çözümün doğrudan Kur'an'a sarılmakta olduğunu şöyle dile getirmiştir:

"Yedi yüz yıllık eserlerle bu dînin hâlâ,

İhtiyâcâtını kâbil mi telâfî? Aslâ.

Doğrudan doğruya Kur'an'dan alarak ilhâmı,

Asrın idrâkine söyletmeliyiz İslâm'1.

Kuru da'va ile olmaz bu fakat ilm ister;

Ben o kudrette adam görmüyorum, sen göster?” ${ }^{83}$

\footnotetext{
${ }^{78}$ Zümer 39/9.

79 "Son ders-i felaket" dediği altıyüz bin müslümanın doğrandığı Balkan savaşıdır.

${ }^{80}$ Ersoy, Safahat, 197-198 (Hakkın Sesleri).

${ }^{81}$ Ersoy, Safahat, 136 (Hasbihâl).

${ }^{82}$ Fatır 35/19-22.

${ }^{83}$ Ersoy, Safahat, 399 (Âsım).
} 
Kur'an, ataların izinden gidip körü körüne taklitçiliği reddetmiştir. ${ }^{84}$ Zira atalar yanılmış ve aklını iyi kullanamamış olabilir. Hz. İbrahim çevresindeki insanları akıl, mantık ve çeşitli delillerle tevhide çağırmışsa da, ${ }^{85}$ onlar bunu kabul etmemiș, "atalarımızın taptığ şeyleri terk edemeyiz, böyle gördük dedelerimizden!” demişlerdir. ${ }^{86}$ Âkif, bu tavrı şöyle ifade etmiştir:

““Böyle gördük dedemizden!' sesi milyonlarca

Kafadan aynı tehevvürle, bakarsın, çıkıyor!

Arş-1 âmâli bu ses tâ temelinden yıkıyor.

"Böyle gördük dedemizden" sözü dinen merdûd;

Acaba sâha-i tatbiki neden nâ-mahdûd?

Çünkü biz bilmiyoruz dini. Evet, bilseydik,

Çare yok gösteremezdik bu kadar sersemlik." 87

Âkif ilmin önemini her firsatta dile getirmiş, "ağaç yaş iken eğilir" atasözüne uygun olarak bu işe, küçük yaştan itibaren okuma yazmayı öğreten mahalle mektebinden başlanılmasını mısralarında şöyle vurgulamıştır:

"Şu cehlimizle musibet mi kaldı uğramadık?

Mahalle mektebi lâzım, düşünmeyin artık!

Felaketin başı, hiç şüphe yok, cehâletimiz;

Bu derde çare bulunmaz - ne olsa - mektepsiz.

Ne Kürd elifbeyi sökmüş, ne Türk okur, ne Arab;

Ne Çerkeş'in, ne Laz'ın var bakın, elinde kitab!

Hülâsa, milletin efrâdı bilgiden mahrum.

Unutmayın şunu lakin: "Zaman: Zamân-1 ûlûm!"»8

\subsection{6. Âkif'in Millet Anlayışı}

Kur'ân'da hayırlı ve seçkin toplumun nitelikleri şöyle ifade edilmiştir: "Siz iyiliği emr eyler, kötülükten nehy eder, Allah'a inanır olduğunuzdan, insanların hayrı için meydana çıkarılmış en hayırlı bir milletsiniz." 89 Âkif ise bu özellikleri taşıyan Müslüman ecdadımızı şu şekilde yâd etmiştir:

"Bir zamanlar biz de millet, hem nasıl milletmişiz:

Gelmişiz dünyâya milliyyet nedir öğretmişiz!

${ }^{84}$ Ebû Mansûr Muhammed el-Mâtürîdî, Kitâbu't-tevḥid, nşr. Bekir Topaloğlu, Muhammed Aruçi (Ankara: İsam Yayınları, 2003), 4; a.mlf., Te'vilâtu Ehl-i Sunne, thk. Mecdî Bâsellûm (Beyrut: Dâru'lKutubi'l-İlmiyye, 2005), 9: 432.

${ }^{85}$ En'am 6/75-83.

${ }^{86}$ Enbiya 21/51-54; Şuara 26/69-77; Ankebût 29/25; Ebû'l-Fidâ İsmail b. Ömer İbn Kesîr, el-Bidâye ve'n-Nihâye, thk. Ali Şîrî (Beyrut: Dâru İhyai't-Turâsi'l-Arabî, 1408/1988), 1: 143-145.

${ }^{87}$ Ersoy, Safahat, 157-158 (Süleymaniye Kürsüsünde).

${ }^{88}$ Ersoy, Safahat, 255 (Fatih Kürsüsünde).

${ }^{89}$ Âl-i İmran 3/110. 
Kapkaranlıkken bütün âfâkı insâniyyetin,

Nûr olup fişkırmışız tâ sînesinden zulmetin;

Emr-i bi'l-ma'rûf imiş ihvan-1 İslâm'ın işi;

Nehy edermiş, bir fenalık görse, kardeş kardeşi.

Kimse haksızlıktan etmezmiş tegafül ihtiyar;

Ferde raci’ sadmeden efrâd olurmuş lerzedar."90

Âkif, bu mısralarıyla ayette belirtildiği gibi her müminin iyiliği emretmek ve kötülüğü engellemek gibi bir görevinin olduğunu, inanan hiç kimsenin "nemelazım" diyemeyeceğini belirtmiştir.

\subsubsection{Diriliş İçin Rahmetin Gerekliliği}

Kur'ân'da farklı ayetlerde insanın dirilişi baharda yeryüzünün canlanmasına, ${ }^{91}$ insanların topraktan çıkıp hayat bulması da otların yerden bitip yeşermesine benzetilmiştir. ${ }^{92}$ Dünyanın sonbaharda bembeyaz bir kefene bürünmesi ve bahar yağmurlarıyla yeniden canlanıp yeşermesi ölülerin tekrar diriltilmesine benzetilerek şöyle buyrulmuştur: “Allah'ın rahmetinin eserlerine bir bak: Arzı, ölümünün ardından nasıl diriltiyor! Şüphesiz O, ölüleri de mutlaka diriltecektir. O, her şeye kadirdir."93 Âkif bu ayeti manzum olarak şöyle yorumlamıştır:

"Çık da bir seyret bahârın cûş -i renga-rengini;

Nefh-i Sûr'un dinle mevca-mevc olan ahengini!

Bir yeşil kan, bir yeşil can yağdırıp, kudret, yere:

Yemyeşil olmuş fezâ; gömgök kesilmiş dağ, dere.

En kısır toprak doğurmuş, emzirir birçok nebât;

Fışkırır bir damlacık ottan, tutup sıksan, hayât!

Bir nesîm ister kımıldanmak için canlar bugün;

Bir nesîm olsun, İlâhî ... Canlanır kanlar bütün.

Nev-bahârın rûhu etsin bir de bizlerden zuhûr...

Yoksa, artık Sûr-i Îsrafîl'e ${ }^{94}$ kalmıştır nüşûr!"95

Âkif, bu şiirdeki ifadeleriyle her şey, hatta ağaçlar ve otlar bile ilâhî rahmetle canlanırken, Müslüman toplumun neden silkinip kendisine gelemediğini sorgulamıştır. Şiirin başlangıcında "Nefh-i Sûr" ifadesiyle Enâm 6/73; Yasin 36/51; Zümer 39/68 gibi

\footnotetext{
${ }^{90}$ Ersoy, Safahat, 199 (Hakkın Sesleri).

${ }^{91}$ Hac 22/5; Fussilet 41/39.

92 Âli İmrân 3/37; Nûh 71/17; Rûm 30/19; Zuhruf 43/11.

${ }^{93}$ Rum 30/50.

94 İsrâfil'in sûra üflemesine işaret edilerek Zümer 39/68. ayete telmihte bulunulmuştur.

${ }^{95}$ Ersoy, Safahat, 204-205.
} 
ayetlere işaret etmiş, yine sonunda da eğer toplum vahyin esintisiyle canlanıp kendine gelmezse İsrâfil'in sûruyla ancak dirilecektir diyerek konuyu aynı yere bağlamıştır.

\subsubsection{Kâinât ve Hayat}

Fatih Kürüsü'nde Âkif vâizi konuşturup önce şu ayeti okur: “Onlar, Allah'1n göklerdeki ve yerdeki kudret ve hakimiyetini ve Allah'ın yarattığı her şeydeki nizamı görmediler mi?..." A6 Âkif bu ayetle tam bir nizam ve intizam içinde işleyen kâinâtı dikkatlere sunmuş, Müslümanların da bundan ibret alarak yanlış tevekkül anlayışını bir kenara bırakıp çalışmalarını istemiş ve şöyle demiştir:

"Bekâyı hâk tanıyan sa'yi bir vazife bilir;

Çalış çalış ki bekâa sa’y olursa hakkedilir." 97

Şiirlerinde çalışmanın önemini vurgulayan Âkif, insanların örnek almaları için değişik örnekler vererek güneşin ve ayın düzenli bir âile sistemi gibi nasıl çalıştı̆̆ını anlatmış, ${ }^{98}$ Müslümanları uyarıp kader, çalışma ve tevekkül gibi İslam'ın temel konularına şöyle dikkat çekmiştir:

"Taleb nasılsa, tabî'̂̂, netice öyle çıkar,

Meşiyyetin sana zulmetmek ihtimâli mi var?

"Çalış" dedikçe şeriat, çalışmadın, durdun,

Onun hesabına birçok hurafeler uydurdun!

Sonunda bir de "tevekkül”" sokuşturup araya,

Zavallı dini çevirdin onunla maskaraya! ${ }^{99}$

Kader nedir, sana düşmez o sırrı istinkâh;

Senin vazîfen itâat ne emerederse İlâh.

O sokmak istediğin şekle girmesiyle kader;

Bütün evâmir-i şer'in olur bir anda heder!

Neden ya, Hazret-i Hakk'ın Resûl-i Muhterem'i

Bu bahsi men' ediyor müminine, ${ }^{100}$ boş yere mi?"

Âkif, aslında anlaşılması zor bir konu olan kader meselesini de Kur'ân'dan ve sünnetten aldığı ilhamla kendi zihninde çözmüş, müslümana düşen görevin yanlış tevekkülü bırakıp kaderi sorgulamadan, elinden geleni yapıp çalışmak olduğunu belirtmiştir.

\subsubsection{Azim ve Yeis}

\footnotetext{
${ }^{96}$ A'raf 7/185.

${ }^{97}$ Ersoy, Safahat, 225, 226, 230, 232, 233, 234.

${ }^{98}$ Ersoy, Safahat, 226-229.

${ }^{99}$ Ersoy, Safahat, 240.

${ }^{100}$ Hadiste şöyle buyrulmuştur: "Kader hakkında ileri geri konuşmayınız; zîra kader, Allah'ın sırrıdır." Bk. Alî b. Husâmiddîn b. Abdulmelik b. Kadîhân el-Muttakî el-Hindî, Kenzu'l-ummâl fî suneni'l-aḳvâl ve'l-ef'âl, neşr. Bekri Hayyani, Saffet Sakka (Beyrut: Muessesetu'r-Risâle, 1985/1405), 1: 132.

${ }^{101}$ Ersoy, Safahat, 242.
} 
Hz. Yakup, oğullarına şunu söylemiştir: “Oğullarım! Gidiniz de Yusuf'la kardeşini araştırınız; hem sakın Allah'ın inâyetinden ümîdinizi kesmeyiniz. Zîrâ kâfirlerden başkası Allah'ın inâyetinden ümîdini kesmez." "102 Âkif bu ibretli kıssadan hareketle ümidini kaybeden ve çaresizliğe mahkûm olan topluma şöyle seslenmiştir:

“Atiyi karanlık görerek azmi birakmak...

Alçak bir ölüm varsa, eminim, budur ancak.

Hüsrâna rıza verme... Çalış... Azmi bırakma;

Kendin yanacaksan bile, evlâdını yakma!

“Îş bitti... Sebâtın sonu yoktur!” deme; yılma.

Ey milîet-i merhume, sakın ye'se kapılma!"103

Âkif genç nesle ümitsizlik aşılayanlara şu serzenişte bulunmuştur:

"Ye'si ezber bilirim, azmi yüzünden tanımam;

Okutan böyle okutmuştu, beğendin mi İmam?"104

Bir ayette "Bir kerre de azmettin mi, artık Allah'a dayan."105 denilerek "azimden sonra tevekkül” emredilmiştir. Âkif bu ayeti yorumlarken önce tevekkülü yanlış anlayanların kanatlerini serdetmiş, sonra onlara işin gerçeğini şu şekilde açıklamıştır:

“Allah'a dayandım!” diye sen çıkma yataktan...

Ma'na-yı tevekkül bu mudur? Hey gidi nâdân!

Ecdâdını, zannetme, asırlarca uyurdu;

Nerden bulacaktın o zaman eldeki yurdu?

Ey yolcu, uyan! Yoksa çıkarsın ki sabâha:

Bir kupkuru çöl var; ne 1ş1k var, ne de vaha!",106

Kur'ân'da, yeryüzünde gezip dolaşmayı, çevreden ibret almayı, rızık peşinde koşmayı emreden ayetlerden ${ }^{107}$ ilham alan Âkif şiirlerinde sürekli çalışmayı vurgulamış, yanlış tevekkül anlayışına sahip toplumu harekete geçirmek için de çok değişik misaller arzetmiştir. Bunun için kendi avını yakalayıp yiyen arslan gibi olup onun artığıyla doyan topal tilki gibi olmamayı tembihleyen ${ }^{108}$ Âkif, hiçbir gayret göstermeden günü savmaya çalışanları, tevekkülü yanlış anlayıp, kuruntu içine düşenleri şiddetle eleştirdiği gibi Rahman'ın rahmetinden ümit kesenleri ${ }^{109}$ de uyarmış ve şöyle demiştir:

"Bu türlü bir hareket mahz-i küfr olur, zira:

\footnotetext{
102 Yusuf 12/87.

${ }^{103}$ Ersoy, Safahat, 193-194 (Hakkın Sesleri).

104 Âkif, Safahat, 388 (Âsım).

105 Al-i İmrân 3/159.

${ }^{106}$ Ersoy, Safahat, 446-447 (Gölgeler).

107 Âl-i İmrân 3/137; En'âm 6/11; Cum'a 62/10.

${ }^{108}$ Ersoy, Safahat, 246-247 (Fatih Kürsüsünde).

109 Yûsuf 12/87; Hicr 15/55-56; Zümer 39/53.
} 
Talepte âmir olurken bir ayetinde Huda;

Buyurdu: "Kesmeyiniz ruh-u rahmetimden umîd;

Ki müşrikin olur ancak o nefhadan nevmîd."110

Âkif' in en sevmediği şey yeis ve ümitsizliktir. İnancı olan insan ümitsizlik ve çaresizlik gibi bahanelere sarılamaz. Nitekim Allah: "Dalâle düșmüşlerden başka kim Rabb'inin râhmetinden ümîdini keser ki?!"111 buyurmuştur. Âkif de bu konuda da uzunza uyarılarını sıralayıp en son şunu söylemiştir:

“Allah'a dayan, sa'ye şarıl, hikmete ram ol...

Yol varsa budur, bilmiyorum başka çıkar yol."112

\subsubsection{Birlik ve Beraberlik}

Kur'ân'da Müslümanların birlik ve dirliği şöyle vurgulanmıștır: “...Biribirinize de girmeyin ki, ma'neviyatınız sarsılmasın, devletiniz gitmesin..." ${ }^{\prime 13} \mathrm{Bu}$ ayeti konu başlığı yapan Âkif şöyle demiştir:

"Sen! Ben! desin efrâd, aradan vahdeti kaldır;

Milletler için işte kıyâmet o zamandır.

Mazilere in, mahşer-i edvârı bütün gez:

Kânûn-i İlâhî, göreceksin ki, değişmez." "114

Birlik-beraberlik ve kardeşliği emreden bir başka ayette de şöyle buyrulmuştur: "Hep birlikte Allah'ın ipine sımsıkı yapışın; parçalanmayın. Allah'ın size olan nimetini hatırlayın: Hani siz birbirinize düşman kişileridiniz de $O$, gönüllerinizi birleştirmişti ve O'nun nimeti sayesinde kardeş kimseler olmuştunuz...". ${ }^{115}$ Âkif bu ayetin muhtevasını manzum olarak şöyle vermiştir:

"Müslümanlık sizi gayet sıkı, gayet sağlam,

Bağlamak lazım iken, anlamadım, anlayamam,

Ayrılık hissi nasıl girdi sizin beyninize?

Fikr-i kavmiyyeti şeytan mı sokan zihninize?

Birbirinden muteferrik bu kadar akvâmı,

Aynı milliyetin atlında tutan İslam'1,

Temelinden yıkacak zelzele, kavmiyettir.

Bunu bir lahza unutmak ebedi haybettir...

110 Âkif, Safahat, 262-263 (Fâtih Kürsüsünde).

${ }^{111}$ Hicr $15 / 56$.

${ }^{112}$ Ersoy, Safahat, 443-444 (Gölgeler/Yeis Yok).

${ }^{113}$ Enfâl 8/46.

${ }^{114}$ Ersoy, Safahat, 440. (Gölgeler).

115 Âl-i İmran 3/103. 
Arnavutlukla, Araplıkla bu millet yürümez.

Son siyasetse bu! Hiç böyle siyaset yürümez!

Sizi bir aile efradı yaratmış Yaradan;

Kaldırın ayrılık esbâbını artık aradan.

Girmeden tefrika bir millete, düşman giremez;

Toplu vurdukça yürekler, onu top sindiremez."116

Âkif dertleri teşhis edip tefrikaya düşenleri eleştirirken çözümün de yine birlik ve beraberlikte olduğunu şöyle vurgulamıştır:

"Değil mi cebhemizin sînesinde îman bir;

Sevinme bir, acı bir, gâye aynı, vicdân bir;

Değil mi sinede birdir vuran yürek... Yilmaz!

Cihân yıkılsa, emin ol, bu cebhe sarsılmaz!"117

\subsubsection{Dua-Naz ve Niyaz}

Hayatı Kur'ân'la yoğrulmuş olan Âkif Allah'a isyan edecek değildir. Ancak hayatın akışı içinde gördüğü bazı acıklı manzaralar ve Müslümanların içine düşmüş olduğu perişan haller zaman zaman onu çılgına çevirmiştir. $O$ bir yandan ümmetin, içine düşmüş olduğu durumdan kurtulması için çalışıp çabalamasını haykırmış, diğer yandan da sürekli Allah'a yalvarıp yakarmıştır. Bize şah damarımızdan daha yakın olan ${ }^{118}$ ve "dua ettiğinizde duanızı kabul ederim"119 buyuran Allah'a, Âkif yine ayetlerin diliyle yalvarmıştır. Öncelikle "Takat getiremeyeceğimiz yükü bize yükleme, Allah'1m...."120 ayetini serlevha yapmış, sonrada şöyle demiştir:

“Ey bunca zamandır bizi te'dib eden Allah;

Ey âlem-i İslâm'1 ezen, inleten Allah!

Bizler ki senin va'd-i İlahîne inandık;

Bizler ki bin üç yüz bu kadar yı1 seni andık;

Ömrün daha en canlı, hararetli çağında,

Çalkanmadayız ye's île hirman batağında!

Kam aldı cihan, biz yine ferdalara kaldık...

Artık bize göster ki o ferdayı: Bunaldık!"121

İlk bakışta bir itiraz ve naz eder gibi görünen Âkif, aslında bu yakarışlarını asırlardır iman edip bu dine hizmet eden ümmet adına yapmaktadır. $\mathrm{Bu}$ ümmetin sürekli

\footnotetext{
${ }^{116}$ Ersoy, Safahat, 168 (Süleymaniye Kürsüsünde).

${ }^{117}$ Ersoy, Safahat, 321-322 (Hatıralar/Berlin Hatıraları).

${ }^{118}$ Kaf 50/16.

119 Bakara 2/186; Mü'min 40/60.

${ }^{120}$ Bakara 2/286.

${ }^{121}$ Ersoy, Safahat, 276-277 (Hatıralar).
} 
ezilmekten ötürü ye's batağına düşmesine gönlü razı olmayan Âkif, yeniden bir ümit elde etmesi için Allah'tan bir rahmet, yardım ve inayet beklemektedir.

\section{Metin Aralarında Kullandığı Ayetler}

\section{1. İmana Dair Ayetler}

\subsubsection{Kurtuluşun Dört Reçetesi: Asr Suresi}

“Asra yemin olsun ki... İnsan gerçekten hüsrândadır. Ancak şu kişiler müstesnadır: Îmân edenler, sâlih ameller işleyenler, birbirlerine hakkı tavsiye edenler ve birbirlerine sabrı tavsiye edenler."122

Asr sûresine göre iman esaslarını tasdîk edenler, İslâm'a uygun ve insanlığa faydalı iyi işler yapanlar, bu gerçekleri birilerine tavsiye edenler, sıkıntılarla karşılaştıkları zaman sebat edenler zararda olmayıp kurtuluşa erenlerdir. Râzî, pazarda gezerken "Sermayesi eriyen bu şahsa merhamet edin!.." diye bağıran bir buz satıcısının feryadını duyunca yanındakilere şöyle der: "Bağıran şu adamın sözü Asr suresinin anlamıdır."123

Asr sûresinde olduğu gibi birçok ayette iman ve salih amel birlikte yer alır. ${ }^{124}$ İman ve salih amel kurtuluşa vesile olduğu gibi birbirlerine hakkı tavsiye edip bu yolda sebat etmek de kurtuluş vesilesidir. ${ }^{125}$ Müminler inandığı doğruları önce kendileri uygular, sonra da diğer insanlara anlatırlar. ${ }^{126}$ Bu nedenle sahabe-i kirâm, bir araya geldiklerinde ve ayrılmadan önce mutlaka Asr sûresini okur, sonra selamlaşarak ayrılırlarmış. ${ }^{127}$ Âkif bu sûrede açıklanan hüsrândan kurtuluşun dört sırrını ve sahabenin bu güzel âdetini şöyle anlatmıştır:

“Hâlık'ın nâ-mütenâhî adı var. En başı Hak.

Ne büyük şey kul için hakkın elinden tutmak.

Hani Ashâb-1 Kirâm “Ayrılalım...” derlerken,

Mutlaka “Sûre-i ve'l-ass"'1 okurmuş. Bu neden?

Çünkü meknûn o büyük sûrede esrâr-1 felâh.

Önce îmân-1 hakîkî geliyor, sonra a'mâl-i salâh.

Sonra hak, sonra sebât. İşte kuzum insanlık.

Dördü birleşti mi sana hüsrân yok artık." "28

Âsım bölümünde Köse İmam'la medreselerin durumunu değerlendiren Âkif, Kur'ân'dan kopuk ve güncel olmayan ilimlerin toplumu bir yere götüremeyeceğini savunurken "Doğrudan doğruya Kur'ân'dan alarak ilhamı, asrın idrakine söyletmeliyiz İslamı” der. Kur'ân'ın ölülere değil, dirilere okunup anlatılması gerektiğini savunur. Müslümanın hakka arka çıkıp her herde hakkı savunması gerektiğini söylerken hüsrana düşmemek için Asr suresinin mealini şiir üslûbuyla aktarır. Çünkü bu sûrede hakkı

\footnotetext{
122 Asr 103/1-3.

${ }^{123}$ Râzî, Mefâtîhu'l-Gayb, 32: 85.

${ }^{124}$ Bakara 2/25, 82, 277; Âl-i İmran 3/57.

125 Âl-i İmran 3/200.

126 Bakara 2/44.

${ }^{127}$ Muhammed Ali es-Sabûnî, Safvetü 't-Tefâsîr, (el-Kâhire: Dâru's-Sâbûnî, 1417/1997), 3: 601.

${ }^{128}$ Ersoy, Safahat, 400 (Âsım).
} 
tavsiye başta olmak üzere kurtuluşun dört esası gizlidir. Zaten Akif için Müslüman; imanı bütün, işi gücü salah, şiârı hak, mesleği sebat olan insandır. Bu insan asla hüsrana uğramaz. Ona göre bu dört sıfatı birleştiren kişi ancak hakiki insan olabilir. ${ }^{129}$

\subsubsection{Bazı Ayetlerden Yapılan Manevî İktibaslar}

Valide Sultanın yalısında okunan mevlid merasimini anlatan Âkif şu beyitleri iktibas etmiştir:

“Sultân-1 Rusül, Şâh-1 Mümecced'sin, efendim!

Bîçârelere devlet-i sermedsin, efendim!

Menşûr-i “Le 'amruk”le müeyyedsin efendim!

Dîvân-1 İlâhî'de ser-âmedsin, efendim!

Sen Ahmed ü Mahmûd u Muhammed'sin, efendim!

Hak’tan bize Sultân-1 Müebbed'sin, efendim!”

Âkif ilgili dipnotta, "Şeyh Gâlib'in meşhûr "Naat"inden alınmış bu mısraralardaki "Le “amruk" ifâdesinin Hicr 15/72. ayetinde yer aldığını ve ve bununla Resûl-i Ekrem Efendimizin hayatına yemin edildiğini belirtmiştir. ${ }^{130}$

Âkif, Fir'avun'u anlatırken mısra aralarında Kur'ân'dan iktibas etmiş ve şunları söylemiştir:

“Bu Fir'avun ki, cehennemdi yerde kâbûsu,

Cehennem olmadan evvel vücûd-i menhûsu;

Bu Fir'avun ki, beşer, korkudan, büküp belini,

Huşû' içinde tavaf eylemişti heykelini;

Bu Fir'avun, bu görünmez kazâ, bu saklı belâ,

Ki bir zaman tapılıp dendi: "Rabbune'1-a'lâ!"

Ne intikâm-1 İlâhî, ne sermedi hüsrân:

Gelen, geçenlere ibret, yatar sefîl, üryan!

Soyulmadık eti kalmış, bilinmiyor kefeni;

Açıkta, mumyası hâlâ dağılmıyan, bedeni.",131

$\mathrm{Bu}$ misralarda Fir'avun'un tanrılık iddias ${ }^{132}$ konu edinilmiştir. Kur'ân'da haber verildiği gibi bir zamanlar Fir'avun insanlara "Ben, sizin en yüce Rabbinizim!" 133 diye iddiada bulunmuş, insanlar da bunu kabul etmişti. Âkif burada bu duruma işaret etmiştir. Son mısralarda ise Fir'avun'un kaybolmayan, çürümeyen ibretlik bedeniyle bir başka ayete ${ }^{134}$ işaret etmiştir.

\footnotetext{
${ }^{129}$ Şiirin önünü sonunu görmek için bk. Ersoy, Safahat, 399-401 (Âsım).

${ }^{130}$ Ersoy, Safahat, 486 (Gölgeler).

${ }^{131}$ Ersoy, Safahat, s. 459-460 (Gölgeler).

${ }^{132}$ Firavun: "Sizin için kendimden başka hiçbir ilah tanımıyorum..." (Kasas 28/38) demişti.

133 Nâziât 79/24.

134 Yunus 10/92.
} 


\subsection{Ahlakî-İçtimâî Konulara Dair Ayetler}

Âkif ahlakî-içtimâî konuları işlerken bazı ayetlere değinmiş, mısra aralarında ayetin tamamını veya bir kısmını iktibas etmiştir. Onlardan bazıları aşağıdadır:

\subsection{1. Çalışmak-Durmamak}

Âkif, "Durmayalım!” adlı şiirinde çalışma, azim ve gayretin önemini şöyle ifade etmiştir:

“Leyse li'l-insâni illâ mâ seâ" derken Hudâ;

Anlamam hiç meskenetten sen ne beklersin daha?

Davran artık kârbânın arkasından durma, koș!

Mahv olursun bir dakîkan geçse hatta böyle boş.

Mâsivâ bir şey midir, boş durmuyor Hâlık bile:

Bak tecellî eyliyor bin şe'n-i gûnâgûn ile.

Ey, bütün dünyâ ve ma fîha ayaktayken, yatan!

Leş misin, davranmıyorsun? Bâri Allah'tan utan."135

Âkif burada "İnsan için kendi çalışmasından başka bir şey yoktur"136 ayetini iktibas ederken "bin şe'n-i gûnâgûn" ifadesi ile de Rahman suresinde yer alan "Göklerde ve yerde bulunanlar, O’ndan isterler. O, her gün yeni bir iştedir." 137 ayetinden manevî iktibasta bulunmuştur.

\subsubsection{Azim, Tevekkül ve Şûrâ/İstişâre Meselesi}

Allah Uhud Savaşı'nın (3/625) ardından şu ayeti indirmiştir: “...Onları aff et; onlar için mağfiret dile; iş hakkında onlara danış; bir kere de karar verdin mi, Allah'a (tevekkül et) dayan..."138 $\mathrm{Bu}$ ayetle Allah her türlü hatalarına rağmen, Peygamberimizin, ashabını affetmesini, onlar için af dilemesini ve işlerinde yine onlarla istişare etmesini emretmiştir. ${ }^{139}$ Zira tek başına alınan doğru karardan ise sonunda yanılma ihtimali olsa bile çoğunluğun aldığ karar daha çok kabul görmektedir. ${ }^{140}$ Karar kesinleşip bir işe azmettikten sonra da Allah'a güvenilmesi emredilmiştir. Âkif bu konuda şöyle demiştir:

“Tevekkül olmaya görsün yürekte azme refîk;

Durur mu şevkine pervâne olmadan tevfîk?

Cenab-1 Hak ne diyor bak, Resül-i Ekrem'ine:

Bütün serâiri kalbin ihâta etse, yine,

\footnotetext{
${ }^{135}$ Ersoy, Safahat, 23-24 (Birinci Kitap/Durmayalım).

136 Necm 53/39.

${ }^{137}$ Rahman 55/29.

138 Âl-i İmran 3/159.

${ }^{139}$ Ebü'l-Hasan Mukatil b. Süleyman b. Beşir Mukatil b. Süleyman, Tefsiru Mukatil b. Süleyman, thk. Abdullah Mahmûd Şehhate (Beyrut: Dâru İhyâi't-Turâsi'l-Arabi, 1423/2002). 1: 300.

${ }^{140}$ Salâh Abdülfettah el-Halidî, et-Tefsîru'l-mevżû̀ beyne'n-naz ariyyeti ve't-taṭîk (Amman: Dârü'nNefâis, 2015/1436), 235-248.
} 
Danış sahabene dünyâya âid işler için;

Rahim ol onlara... Sen, çünkü, rûh-i rahmetsin.

Hata ederseler aldırma, affet, ihsân et;

Sonunda hepsi için iltimâs-1 gufrân et.

Verip kararı da azm eyledin mi... Durmıyarak

Cenab-1 Hakk'a tevekkül edip yol almaya bak.

Hülâsa, azm ile me'mûr olursa Peygamber;

Senin hesabına artık, düşün de bul, ne düşer?!"141

Manzûm olarak tercüme ettiği bu ayetten hareketle Âkif, Peygamberimize (s.a.v.) bile emredilen istişare, azm ve sebat gibi hususların ümmetini daha çok bağlayacağına vurgu yaparak toplumu gayrete ve harekete getirmeye çalışmıştır.

\subsubsection{Nifak ve Fitne}

Samimi müminlerin gönülleri birdir. ${ }^{142}$ Aynı dine inanan ve aynı kıbleye yönelen insanlar birbirlerini kardeş bilirler. ${ }^{143}$ Münafiklar görüntüde birlik-beraberlik içinde olsalar da aslında onların kalpleri dağınıktır, fikirleri başka başkadır. Kur'ân' da: 'Kendi aralarında çekişmeleri şiddetlidir. Sen onları toplu sanırsın, oysa onların kalbleri ayrı ayrıdır..." buyrulmuştur. ${ }^{144}$ Âkif bu ayete telmihte bulunarak bölünme ve tefrikayı nifak alameti saymış ve şunları söylemiştir:

"Neden uhuvvetiniz böyle münhasır namaza?

Çıkınca avluya herkes niçin boğaz boğaza?

Ne Müslümanlığıdır, anlamam ki, yaptığınız?

Çıkar yol olmıyacak, korkarım, bu saptığınız!

Görünce fesli, atılmak, tasarlayıp bıçağı;

Görünce şapkalı, sinmek, değiştirip sokağı;

Gönüller ayrı oluş, sineler bir olsa bile...

Nifak alâmeti bunlar, kuzum, tamamiyle:

Nifaka buğz ediniz hâlisen li-vechillah;

Halas eder sizi ihlâsınızla belki îlah.

$\cdots$

Yanında yaş da yanar, çaresiz, yanan kurunun...

Diyor Kitab-1 Îlâhî: “O fitneden korunun,

Ki sade sizdeki erbâb-1 zulmü istilâ

\footnotetext{
${ }^{141}$ Ersoy, Safahat, 244-245 (Fatih Kürsüsünde).

142 Âl-i İmrân 3/103; Enfâl 8/63.

143 Tevbe 9/11; Hucurat 49/9-10.

${ }^{144}$ Haşr 59/14.
} 
Eder de, suçsuz olan kurtulur değil asla!...”

Hesab edin ne kadar bigünahın aktı kanı...

Beş on vatansız için nara yakmayın vatanı!

Huda rızası için kaldırın nifakı... Günah!

Alev saçaklara sarsın mı, ya ibâdallah?

Sararsa hangimizin hânümanı kurtulacak?

O bir tutuşmaya görsün, ne od kalır, ne ocak!" 145

Bu şiirde "Diyor Kitab-1 Îlâhî: "O fitneden korunun,..." kısmıyla şu ayetten iktibas edilmiştir: "O fitneden sakının ki, aranızdan yalnız haksızlık edenlere erişmekle kalmaz..."146 Böylece Âkif Müslümanları nifak ve fitneye karşı uyarmaya, başlarına gelebilecek felaketlerden korumaya çalışmıştır.

\section{Manevî İktibasla İşaret Edilen Ayetler}

Âkif bazen ayetin bir kısmını zikrederek bir mevzuya işaret etmiş bazen de ayeti zikretmeden o ayetin mana ve muhtevasını izah etmeye çalışmıştır. Fakat görülen o ki Âkif, bir Kur'ân aşığı olup, bütün ilhamını Kur'ân'dan almıştır.

\section{1. İmana Dair Ayetler}

\subsection{1. "Tevhid Yahud Feryad" Adlı Şiirinde Manen İktibas Edilen Ayetler}

Tîn suresinde insanoğlunun mükemmel yaratıldığı bildirilmiş, ardından "Sonra da onu aşağıların en aşağısına düşürdük."147 buyrularak iman ilkelerine uymayan ve salih amel işlemeyen kişilerin düşeceği konum belirtilmiştir. Âkif bu ayete şöyle işarette bulunmuştur:

"Eşbâha mı kurbün olacaktır cevelângâh?

Ervâh bütün mündehiş-i "sümme radednâh!"

Aynı şiirin devam eden mısralarında Yaratıcı'ya hitap ederek şunları söylemiştir:

"Sensin yaratan, başka değil zulmeti, nûru;

Sensin veren ilhâm ile takvâyı, fücûru!"

İlk mısrada "Hamd, gökleri ve yeri yaratan, karanlıkları ve aydınlığı var eden Allah'a aittir..." ona fücurunu ve ondan sakınmayı ilham edene" "149 ayetlerine işaret etmiştir. Aynı şiirin devam eden bölümlerinde Kur'ân'dan aldığı ilhamla şunları söylemiştir:

"Sendense eğer çektiğimiz bunca devâhî,

Kimden kime feryâd edelim söyle İlâhî?

"Lâ yüs'el”e binlerce suâl olsa da kurban,

\footnotetext{
${ }^{145}$ Ersoy, Safahat, 260-261.

${ }^{146}$ Enfal 8/25.

147 Tîn 95/4-5.

${ }^{148}$ En'âm 6/1.

149 Şems 91/7-8.
} 
İnsan bu muammâlara dehşetle nigehban.

Bu misralarda "Lâ yüs'el” diyerek daha önce zikri geçen Enbiya 21/23. ayete atıfta bulunmuştur. Aynı şiirin devamında da iman-küfür mukayesesinde bulunmuştur. ${ }^{150}$

\subsubsection{Kur’an'ın Hayatımızdaki Yeri ve Önemi}

İnsanların geneli Kur'ân'1 daha çok mezarlıktaki ölülere okuyup üfleseler de Kur'ân ölümsüz Allah ${ }^{151}$ katından gelmiş olup, onun içindeki emir ve yasaklar insanlara hayat veren ruh gibidir. ${ }^{152}$ Kur'ân da şiir değil, dirileri uyarmak için indirilmiş bir zikir/mesajdır. ${ }^{153}$ Âkif, doğrudan bu ayetleri vermese de aşağıda söyledikleri tamamen bu ayetlerin ruhunu yansitmaktadir:

"Ya açar bakarız Nazmı Celilin yaprağına

Ya da üfler geçeriz bir ölünün toprağına

İnmemiştir hele Kur'an şunu hakkıyla bilin

Ne mezarlıkta okunmak, ne de fal bakmak için" 154

Bir başka şiirinde de şunu söylemektedir:

“Ölüler dîni değil, sen de bilirsin ki bu din,

Diri doğmuş, duracak dipdiri, durdukça zemin."

Bu şiirlerin devamında imanı sağlam, yürekli ve cesaretli Mandal lakaplı Oflu Hoca'dan söz ederek şöyle demiştir:

“O nasil kalb, o nasil azm, o nasil itminan?..

İşte tevfîk-1 İlâhî 'ye yürekten inanan;

İşte "la havfe aleyhim" diye Kur'an-1 Hakim,

Bu velî zümreyi etmektedir ancak tekrîm."

Âkif yukarıdaki şiirde geçen "la havfe aleyhim" lafzı için dipnotta şu izahı yapar: "Nazm-1 Celil'deki (la havfe) fa'nın fethiyle -Yâ'kûb kıra'atine göre- okunmalıdır."157 Bu da Âkif'in Kur'ân'ın mana ve muhtevasıyla birlikte kıraat ilmine de vâkıf olduğunu göstermektedir. "Onlara korku yoktur" şeklindeki bu ifade, Kur'ân'ın on dört ayetinde geçmektedir. ${ }^{158} \mathrm{Bu}$ ayetlerde, iyi insanların vasıfları ve yaptıkları hayırlı işler sayıldıktan sonra "lâ havfun aleyhim ve lâ hum yahzenun/ Onlara hiçbir korku yoktur ve onlar üzülmeyeceklerdir" 159 buyrulmuştur.

\subsection{Ahlakî-İçtimâî Konulara Dair Ayetler}

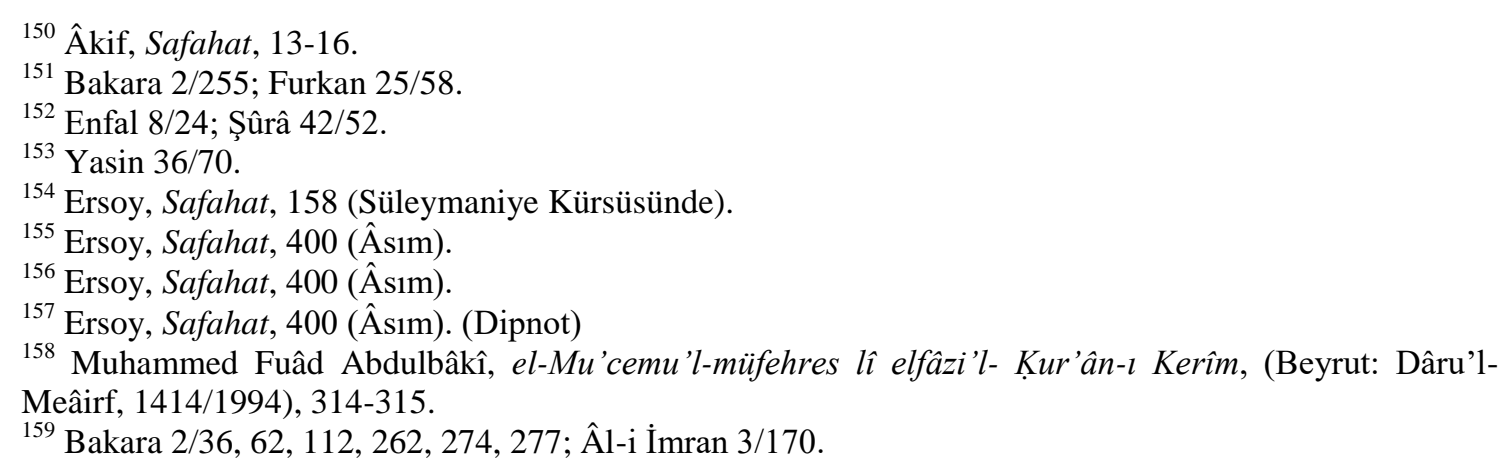




\subsection{1. İnsan}

İslam mükemmel bir din, insan mükerrem bir varlıktır. ${ }^{160}$ Çünkü özünde ilahî ruh taşıyan insan ${ }^{161}$ kâinatın bir özeti hükmündedir. Hz. Ali bu konuda şöyle demiştir: "Ve tez'umu enneke cismun șagînrun- Ve fîke ințave'l-'âlemu'l-ekber" Yani "Sen kendinin küçük bir cisim olduğunu sanırsın. Ama bütüm âlem senin içine sığdırılıp gizlenmiştir." Âkif, Hz. Ali'nin bu şiirini alıp onun yorumunda insanın mahiyetini, mana ve önemini şöyle anlatmıştır:

"Haberdar olmamışsın kendi zatından da hâlâ sen,

"Muhakkar bir vücûdum" dersin ey insan, fakat bilsen...

Senin mahiyyetin hatta meleklerden de ulvîdir: ${ }^{162}$

Avâlim sende pinhandır, cihânlar sende matvîdir;

Esirindir tabîat, dest-i teshîrindedir eşya;

Senin ahkâmının münkadıdır, mahkûmudur dünyâ."163

Âkif, ayetleri direkt kullanmasa da mısralarında "dest-i teshîrindedir eşya" ifadeleriyle insanoğlunun emrine verilen (musahhar k1lınan) kâinata dikkat çekmiştir. ${ }^{164}$ İnsan kâinâtın gözbebeğidir, Allah'ın yarattı̆̆ı en değerli varlıktır. Ancak ilâhi kudret ve ilim karşısında nerede duracağını, gücünü ve sınırlarını da bilmek durumundadır. Âkif bir başka şiirinde de - Yaratıcı'nın lisânından- insana bu mahiyetini ve sınırlarını şöyle hatırlatmıştır:

"Senin o sahada yoktur işin! O saha, benim,

Bütün halâika mesdûd Kâbe Kavseyn'im! ${ }^{165}$

Harîmi zâir-i tahmin için küşâde değil;

Saray-1 vahdetimin durma karşısında, çekil!

Çekil de feyz-i mübînimle tâ ezelde sana

Müsahhar eylediğim bir cihânın ortasına

Atı1... Fezâyı dolaş, âsümana çık, yere in;

Lisân-1 gaybım olan beyyinat-1 hikmetinim,"166

Bu mısralarda insanoğluna bilgisinin ve gücünün sınırlı olduğu ve kendi gücü ve sahasına giren alanda çalışıp üretmekle mes'ûl olduğu vurgulanmıştır.

\subsubsection{Süleymaniye Camiinin Girişinde Bir Ayet}

\footnotetext{
${ }^{160}$ Mâide 5/3; İsra 17/70; Tîn 95/4.

${ }^{161}$ Hicr 15/29; Secde 32/9; Sâd 38/72.

162 İnsan mahiyet itibariyle meleklerden üstün olduğu için melekler kendisine secde etmiştir: Bakara 2/34.

${ }^{163}$ Ersoy, Safahat, 66-67 (İnsan).

${ }^{164}$ Kâinât ve içindekiler insanın emrine amadedir: Bk. İbrahim 14/32-33; Nahl 16/12-14; Hac 22/37, 65; Lokman 31/20; Casiye 45/12-13.

${ }^{165}$ Burada "Kâbe Kavseyn'im” Necm sûresinin 53/9. ayetine işaret edilmiştir. "İki yay kadar" demek olan bu ifade ile Allah'ın zatına mahsus özel bilgi alanları kastedilmiştir.

166 Âkif, Safahat, 230 (Fatih Kürsüsünde).
} 
Süleymaniye camiinin girişinde namazın vakitlere bağlı farz bir ibadet olduğunu bildiren şu ayet mevcuttur: "Namazı bitirince de ayakta, otururken ve yanınız üzerinde yatarken (daima) Allah'ı anın. Huzura kavuşunca da namazı dosdoğru kılın; çünkü namaz müminler üzerine vakitleri belli bir farzdır."167 Âkif de "Süleymaniye Kürsüsünde" adlı şiirinde camiye girmeden önce gördüklerini anlatırken namazın emredildiği bu ayete şöyle telmih yapmıştır:

“Bir musanna' kemer, üstünde kurulmuş Tevhîd;

Daha üstünde bir ayet ki: Huda' dan te'yîd,

Emr-i mevkût-i salâtın bize kat'iyyetine.

Şöyle bir baktı mı insan, kapının hey’etine,"

Âkif, burada özellikle "Emr-i mevkût-i salâtın bize kat'iyyetine" ifadeleriyle "inne’s salâte kânet 'ale'l-mü'minîne kitâben mevkûtâ" ifadesine işaret etmiş, özellikle buradaki "inne" edatının kesinlik bildirdiğini de vurgulamıştır.

\subsection{3. Şehitlere Dair}

Kur'ân'da şehitlerin diri olup rableri katında rızıklandıkları bildirilmiştir. ${ }^{169}$ Bir ayette de Allah'a verdiği sözü yerine getirip canını verenlerle can vermek için nöbetini bekleyenler övülmüştür. ${ }^{170}$ "Âssım” bölümünde "Çanakkale Şehitlerine" adlı şiirde Âkif şehitlere dair şunları söylemiştir:

"Şüheda gövdesi, bir baksana, dağlar, taşlar...

$\mathrm{O}$, rüku' olmasa, dünyaya eğilmez başlar,

Vurulup tertemiz alnından, uzanmış yatıyor,

Bir hilal uğruna, ya Rab, ne güneşler batıyor!"171

Burada Allah'a ruku'u yapma dışında şehitlerin hiçbir güç ve kuvvetin karşısında eğilmeyeceği, boyun eğmeyeceği anlatılmıştır. Hilâl kelimesinin Arapçası (هلال/hilâl) ile Allah (الله/Allâh) kelimesinin harfleri aynıdır. Dolayısıyla Hilâl, Allah'ı sembolize eder. Nasıl ki batı ufkunda Hilâlin gözükmesi için güneşin batması gerekiyorsa, "Allah" adının yücelmesi (i’lây-1 kelimetullah) için de güneş gibi yüce ve tertemiz olan Mehmetçiğin can verip şehit olması gerekmektedir.

\subsubsection{Mezarlık}

Eyüp Sultan mezarlığını dolaşan Âkif orada gördüğü bir manzarayı şu şekilde nazma dökmüştür:

“Ey mezaristan, nihan ka'rında yüz binlerce mâh,

F1şkıran hâk-i remîminden bütün nûr-i nigâh!",172

\footnotetext{
${ }^{167}$ Nisa $4 / 103$.

${ }^{168}$ Ersoy, Safahat, 146. (Süleymaniiye Kürsüsünde).

169 Bakara 2/154; Âli İmrân 3/169.

${ }^{170}$ Ahzab 33/23.

${ }^{171}$ Ersoy, Safahat, 408 (Âsım).

${ }^{172}$ Ersoy, Safahat, 38. (Mezarlık)
} 
Âkif, burada çürümüş kemiklerden oluşan mezar toprağının kastedildiği "hâk-i remîm" tabiriyle, “...Şu çürümüş kemikleri kim diriltecek?"173 ayetinden manevî iktibasta bulunmuştur. $\mathrm{Bu}$ şiirin devamında mezarlıkta görüp duyduklarını şöyle anlatmıştır:

"Fakat bu beste-i lâhût nereden aksediyor,

Ki "Ellezî haleka'l-mevte ve'1-hayâte..." diyor?",174

"Gözüm, uzaktaki bir medfenin ayak ucuna

Çöküp ziyâret eden, bir çocukla bir kadına

İlişti. Sonra biraz yaklaşınca, iyden iyi,

Tezahür eyledi: Baktım, çocuk "Tebâreke"yi

Kemâl-i vecd ile ezber tilâvet eylemede;

Yanında annesi gözyaşlarıyle dinlemede.

Çocuk hayâta, o makber de mevte bir levha.

Tezâd-1 kudreti gör: Bak şu levh-i zîrûha!"175

Âkif, mezarlıkta okunan Tebârake'nin ilk ayetlerinden ilham alarak çocuğu hayatın bir örneği, mezardakileri de ölümün örneği yaparak kudret sanatındaki zıtlığa dikkat çekmiştir. Böylece ayetlerde soyut kayramlarla ifade edilen ölüm ve hayatı adeta canlı bir şekle büründürmüştür.

\subsubsection{Zulme Meyletmemek}

Kur'ân'da birçok yerde zulüm yasaklanmış, bir ayette “... ne haksızlık etmiş ne de haksızlığa uğramış olursunuz."176 buyrulmuştur. Yine zalimlere meyledilmemesi şöyle emredilmiştir: "Zulmedenlere meyletmeyin; sonra size ateş dokunur..."177 Âkif hep zulme karşı durmuş ve konuyu şöyle değerlendirmiştir:

"Zulmü alkışlayamam zalimi asla övemem.

Gelenin keyfi için geçmişe kalkıp sövemem.

Üç buçuk soysuzun ardında zağarlık yapamam

Hele hak namına haksızlığa ölsem tapamam.

Biri ecdadıma saldırdı mı hatta boğarım.

Boğmazsam bile hiç olmazsa yanımdan koğarım.

Ben ezelden beridir aşıkım istiklâle.

Bana hiç tasmalık etmiş değildir altın lâle.

\footnotetext{
173 Yâsîn 36/78.

${ }^{174}$ Mülk 67/2. ayetin tamamı şöyledir: "Hanginizin daha güzel iş ortaya koyacağını denemek için, ölümü ve hayat1 yaratan O'dur..."

${ }^{175}$ Ersoy, Safahat, 40 (Mezarlık).

176 Bakara 2/279.

${ }^{177}$ Hud 1/113.
} 
Yumuşak başlı isem kim demiş uysal koyunum.

Kesilir belki fakat çekmeye gelmez boyunum.

Kanayan bir yara gördüm mü yanar tâ ciğerim

Onu dindirmek için kamçı yerim, çifte yerim.

"Adam aldırma da geç git.." diyemem aldırırım

Çiğnerim, çiğnenirim, Hakk’1 tutar, kaldırırım.

Zalimin hasmıyım amma severim mazlumu

İticanın şu sizin lehçede anlamı bu mu?"

Yukarıda verilen Asr suresinin manzum tercümesini de Âkif yine zulme karşı çıkıp haktan yana, hak taraftarı ve hakka destek olma bağlamında değerlendirmiştir.

\subsubsection{Peygamberimiz Hz. Muhammed Mustafa'nın Dünyayı Teşrîfi}

Peygamberimizin dünyaya gelişi genelde insanlık için bir rahmet, ${ }^{179}$ özelde müminler için bir lütuf olmuştur. ${ }^{180} \mathrm{Bu}$ durum Kur'an'da: “Andolsun size kendinizden öyle bir Peygamber gelmiştir ki, sizin sıkıntıya uğramanız ona çok ağır gelir. $\mathrm{O}$, size çok düşkün, müminlere karşı çok şefkatlidir, merhametlidir."181 İnsanlık kardeşlik ve dostluğu ondan öğrenmiş, onun getirdiği ilâhî mesajlar sayesinde yıllardır birbirine düşmanlık eden insanlar onun gelişiyle dost oluvermişlerdir. ${ }^{182}$

Âkif, "Bir Gece” adlı şiirinde Peygamberimizin dünyaya gelişini şöyle anlatmıştır:

"On dört asır evvel, yine böyle bir geceydi

Kumdan, ayin on dördü, bir öksüz çıkıverdi!

Lâkin o ne hüsrandı ki; hissetmedi gözler;

Kaç bin senedir, halbuki, bekleşmedelerdi!

Nerden görecekler? Göremezlerdi tabi:

Bir kerre, zuhur ettiği çöl en sapa yerdi;

Bir kerre de, ma'mure-i dünya, o zamanlar,

Buhranlar içindeydi, bugünden de beterdi.

Sırtlanları geçmişti beser yırtıcılıkta;

Dişsiz mi bir insan, onu kardeşleri yerdi!

Fevza bütün afakını sarmıştı zeminin,

Salgınd1, bugün şark'1 yıkan, tefrika derdi.

Derken, büyümüş, kırkına gelmişti ki öksüz,

\footnotetext{
${ }^{178}$ Ersoy, Safahat, 377 (Âsım).

${ }^{179}$ Enbiyâ 21/107; Sebe 34/28.

180 Âl-i İmrân 3/164; Cum'a 62/2.

181 Tevbe 8/128.

182 Âl-i İmrân 3/103.
} 
Başlarda gezen kanlı ayaklar suya erdi!

Bir nefhada insanlığı kurtardı o masum,

Bir hamlede Kayserleri, Kisraları serdi!

Aczin ki, ezilmekti bütün hakkı, dirildi;

Zulmün ki, zeval aklına gelmezdi, geberdi!

Medyundur o Masum'a bütün bir beşeriyyet...

Ya Rab, bizi mahşerde bu ikrar ile haşret."

$\mathrm{Bu}$ şiirinde de yine ayetlerden aldığı ilhamla Âkif, Peygamberimizin (s.a.v.) insanlık için nasıl bir rahmet olduğunu açıkça ifade etmiştir.

\subsubsection{Yağcılık ve Yaltaklanma Üzerine}

Kur'ân'da güzel konuşup güzel amel işlemek emredildiği ${ }^{184}$ gibi hak namına gerçekleri söylemek de emredilmiş ve birine yaranmak için gerçek dışı bir şey söylemek yasaklanmıştır. ${ }^{185}$ Bir ayette şöyle buyrulmuştur: "O halde, (hakikati) yalan sayanlara boyun eğme! Onlar isterler ki, sen yumuşak davranasın/yağcılık yapasın da onlar da sana yumuşak davransınlar/yağcılık yapsınlar. ... Mal ve oğulları var diye onlara boyun eğme." 186

$\mathrm{Bu}$ ayetlerde geçen "tudhinu-yudhinûne" kelimeleri "yağ" anlamına gelen "duhn" ve "dihân"187 kelimelerinden türemiş olup "yağlamak, yağcılık yapmak, yaltaklanmak..." anlamlarına gelir. ${ }^{188}$ Aynı kökten türeyen "müdhinun"" kelimesi de yalancılar ve kâfirlerin tarafına meyledenler anlamına gelmektedir. Bunların, yerine göre müslümanlara, duruma göre de müşriklere yağcılık yapan münafiklar ${ }^{190}$ olduğu da söylenmiştir. ${ }^{191}$ Oysa ki müslüman yağccllı yapmaz. Asr-1 saadette Medine’ye hicretten önce Habeşistan'a hicret eden sahabîler ${ }^{192}$ huzuruna sığındıkları kral Necaşi'ye bile yağcılık yapmamışlardır. Müslümanların bu sağlam karakterinden ve verdikleri bilgilerden $^{193}$ etkilendikleri için Habeşistan'dan bir heyet gelip inceleme yaparak Müslüman olmuşlardır. Bunun üzerine bazı ayetler ${ }^{194}$ nâzil olmuştur. ${ }^{195}$

\footnotetext{
${ }^{183}$ Ersoy, Safahat, 478 (Gölgeler).

184 İsra $17 / 53$.

${ }^{185}$ Enam 6/52; Kehf 18/28.

${ }^{186}$ Kalem 68/8-14.

${ }^{187}$ Bu kelimelerin geçtiği diğer ayetler için bk. Müminun 23/20; Rahman 55/37.

${ }^{188}$ Rağıb, Müfredât, 250; Zemahşerî, el-Keşşâf, 4: 59.

${ }^{189}$ Vak1'a 56/81.

${ }^{190}$ Bakara 2/14; Âl-i İmran 3/119.

${ }^{191}$ Ebû Ali Eminüddin Fazl b. Hasan b. Fazl Tabersî, Mecmaü'l-beyân fî̀ tefsîri'l-Kur'ân, nşr. Haşim erResüli Mahallati, Fazlullah el-Yezdi et-Tabatabai (Beyrut: Dârü'l-Ma'rife, 1406/1986), 6: 132.

192 İbrahim Sarıçam, Hz. Muhammed ve Evrensel Mesajı (Ankara: Diyanet İşleri Başkanlığı, 2002), 101, 104.

${ }^{193}$ Müslümanlar oraya gitmeden once Hz. İsa ve Meryem hakkında bazı ayetler (Meryem 19/1-40) indiği gibi nasıl davranacaklarını bildiren ayetler (Ankebût 29/46) de gelmiştir. Müslümanları Necâş̂̀'den geri isteyen Mekkeli müşriklere karşı, Cafer b. Ebi Talib de vakarlı bir konuşma yaparak kendilerini savunmuştur.

${ }^{194}$ Maide 5/82-85; Kasas 28/52-55.
} 
Âkif, bu konuda öncelikle müslümanın nerde durması gerektiğini şöyle anlatmıştır:

"Müslüman hakka zâhir olmaya her an mecbûr,

Sarsılır varlı̆ğ, göstermeye başlarsa fütûr."

Sonra zalime karşı mazlumdan yana olan Hz. Ömer'in tavrını nakletmiş, ancak etrafını yağcı güruh sardığı zaman $\mathrm{Hz}$. Ömer bile olsa kişinin doğru davranamayacağını vurgulamıştır. Çünkü dalkavuklar her iktidara gelenin anlayışına göre yeni bir şekil alır, iktidara gelen dindar biriyse ona göre gerek kılık kıyafet gerekse söz ve tavırlarında sahte bir hüviyete bürünürler. Âkif bu konuda şunları söylemiştir:

"Sofusun farz edelim, şimdi de boy boy tesbih...

Dalkavuklar bütün insan kesilir, la-teşbîh!

Taylasan, cübbe, sarık, hırka, hep esbâb-1 riya,

Dış yüzünden Ömer'in devri muhîtin gûya.

Kimi sâim, kimi kâim, o tavanlar, yerler,

"Kul hüva'llahu ehad" zemzemesinden inler.

Sen bu coşkunluğa istersen inan, hepsi yalan,

“Hüve"nin merci'i artık ne "ehad"dir, ne filan.

Çünkü mâdem yürüyen sâde senin saltanatın,

Şimdilik heykeli sensin tapılan menfa'atın.

Kanma, hey kukla kıyafetli adam, hey sersem,

Herifin ağz1 "samed", mi'desi yüzlerce "sanem!"

Âkif' in bu tasvirinde dalkavukların kimi oruçludur, kimi kıyamda İhlâs suresini okur. Fakat bunlar ağzıyla "Allah birdir" veya "Allahu's-samed" dese de içinde asıl taptığ1 binlerce putu vardır. İktidarda olan dindar kişi gücünü kaybeder de yerine başka meşrepten biri gelirse bu riyakârlar gerçek yüzlerini o zaman gösterir, gidene söverler. Eğer yeniden dindar biri iktidara gelirse dalkavuklar hemen kılık değiştirir, tekrar yeni güç sahibine yaranmak için türlü sözler sarfederler. Âkif bu münafikça tavırları da eserinde uzun uzun tasvir edip eleştirmiştir. ${ }^{196}$ Ancak buradaki "ehad, samed, sanem, huvenin mercii..." gibi kavramlar Kur'ân'1 ve onun dili olan Arapça'yı bilmeden yazılabilecek şeyler değildir. Âkif, bu tür ifadelerle de Kur'ân'a olan vukufiyyetini ve şiirlerini yazarken bütün ilhamını Kur'ân'dan aldığını göstermiştir.

\subsubsection{Kissadan Hisse}

Kur'an'da örnek ve ibret olması için tarihteki kıssalardan bahsedilmiştir. Kamer sûresinde bazı kıssaların ardından şöyle buyrulmuştur: "Biz Kur'an’ı ögüt alınsın diye kolaylaştırdık. Öğüt alan/ düşünen var mı ki?!"197

Âkif de bu konuda şunları söylemiştir:

\footnotetext{
${ }^{195}$ İbn 'Atıye, el-Muharraru'l-Vecîz, 2: 225-227; Elmalıl1, Hak Dini Kur'ân Dili, 3: 1796.

${ }^{196}$ Ersoy, Safahat, 405 (Âsim).

${ }^{197}$ Kamer 54/17, 22, 32, 40.
} 
“Geçmişten adam hisse kaparmış... Ne masal şey!

Beş bin senelik kıssa, yarım hisse mi verdi?

"Tarih"i "tekerrür" diye tarif ediyorlar;

Hiç ibret alınsaydı, tekerrür mü ederdi?"198

\section{Sonuç}

Âkif, Kur'ân ruhu ve vahiy kültürüyle yetiştiği için ümmet-i Muhammed'in derdini kendine dert edinmiş, gördüğü problemlerin çözümüne dair yine Kur'ân'dan çareler ve çözümler arama gayreti içinde olmuştur. Bu aşk ve gayret içinde olan Âkif ilk şiirini Kur'ân hakkında yazmış, sonra yazdığı tüm şiirlerinde de Kur'ân'dan aldığı ilhamla şiirlerini yazmaya çalışmıştır. O, ayrıntıda boğulmadan toplumun dertlerine çareler sunacak ayetleri işleyerek sosyolojik çareler üretmeye çalışmıştır.

Safahat ve diğer dergilerdeki şiirlerinde Âkif, Kur'ân'ın ruhunu manzume tarzında halkın anlayışına sunmuştur. Bu bağlamda onun şiirlerini şiirsel bir tefsir olarak görmek mümkündür. İsteyen kişi Kur'ân'da kendine uygun bir çare ve çözüm bulduğu gibi ilhamını Kur'ân'dan alan Âkif'in şiirlerinde de toplumun dertlerine uygun bir çözüm bulabilmektedir.

Âkif’le ilgili çok farklı çalışmalar yapılmış, eserler yazılmış, yazılmaya da devam etmektedir. Yapılan çalışmalar sayesinde her geçen gün Âkif' in geçmişte olduğu gibi günümüzde de Müslüman toplumlar açısından ne kadar önemli fikirlere sahip olduğu anlaşılmaktadır. Bu çalışmada onun fikirlerinin özünde Kur'an anlayışının olduğu çeşitli örmeklerle ortaya konulmaya çalışılmıştır.

Bu çalışmada Âkif'in sadece bilinen belirli şiirleri değil, Safahat'ında doğrudan veya dolaylı olarak Kur'ân'dan ilham alınarak yazılmış tüm şiirlerine yer verilmeye çalışılmıştır. Ancak ortamın kısıtlı oluşundan ötürü bu şiirlerin geniş izahlarına yer verilememiştir. Bir makalenin hacmi ve ölçüleri içinde şiirlerin daha kolay anlaşılması için ipucu sayılabilecek bazı özet bilgiler sunulmuştur. İlerde belki bu bir tez veya kitap olarak tasarlanabilse de şimdilik bu kadarıyla iktifa edilmiştir. Esasen Âkif'in şiir ve yazılarının tamamı bir şekilde Kur'ân'ın ruhuyla bağlantılıdır. Çünkü çocukluğundan itibaren Kur'ân-1 Kerîm'le yoğrulmuş bir zihin ve gönül dünyasının ondan ilham almaksızın şiir yazması da düşünülemez. $\mathrm{Bu}$ nedenle onun bütün eserleri Kur'ân ayetlerinin gölgesinde incelenip değerlendirilse abartı sayılmaz.

Netice olarak Âkif, toplumu Kur'ân 1şığında değerlendirıniş, Kur'andan hareket ederek toplumu iyileștirme yollarını aramıştır. Kur'an'ın hidayet ve rehberliğini, ona uygun düşünceyi millete mal etmek istemiştir. Bu maksad için, özellikle sosyal hayatla ilgili ayetlere ve·onların tefsirlerine ağırlık vermiş, şiirlerinde bunu gaye edinmiştir. Âkif, Kur'an'1 adeta yeni nazil oluyormuşcasına okumaya gayret etmiş, Kur'anın esas muhatabı sanki kendisi ve içinde yaşadığı toplummuş gibi düşünmüş, böylece Kur'ân'ın muhataplarından beklediği tarzda- ondan büyük bir feyz almıştır. Her türlü tasavvurun üstünde bir dinamizme sahip olan Kur'ân'1, dinamik bir şekilde anlamaya gayret göstermiştir. Şiirin büyüleyici etkisinden istifade ederek, yapay bir sanat

\footnotetext{
${ }^{198}$ Ersoy, Safahat, 475 (Kitalar).
} 
anlayışından uzak, tamamen gönlünden kopanları, yaşanan gerçek olayları samimiyetle yazdığ1 ve özellikle de ebedî olan Kur'an'ın ruhunu yansıtmaya çalıştığı için, Safahat adlı eseri ve şiirleri de kısa zamanda solup gidecek bir çiçek gibi değil, asırlarca gölgesinden istifade edilecek bir çınar hüviyetine bürünmüştür.

\section{Kaynakça}

Abdulbâkî, Muhammed Fuâd. el-Mu'cemu'l-müfehres lî elfâzi'l- Kur'âni'l-Kerîm, Beyrut: Dâru'l-Meâirf, 1414/1994.

Aclûnî, Ebu'l-Fida İsmail b. Muhammed. Keşfü'l-hafâ ve muzîlu'l-ilbâs ammâ iştehere mine'l-ehâdîs ala elsineti'n-nâs. Thk. Abdulhamîd b. Ahmed b. Yusuf b. Hendâvî. Beyrut: el-Mektebetü'l-'Asriyye, 1420/2000.

Aydar, Hidayet. 'Bir Kur'ân Müfessiri Olarak Mehmed Âkif”, Diyanet İlmi Dergi, 32/4 (1996): 25-50.

Abbas, Fadıl Hasan. Kașașu'l-Kur'âni'l-Kerîm. Amman: Dâru'n-Nefâis, 1430/2010.

Beyzâvî, Nâsıruddin Abdullah b. Ömer. Envâru't-tenzîl ve esrâru't-te'vîl, thk. Muhammed Abdurrahman el-Mar'aşlî. Beyrut: Dâru İhyâi’t-Turâsi'l-Arabî, 1418/1998.

Bilgiz, Musa, “M. Âkif'in Şiir ve Düz Yazılarında Kur'ân'dan Temalar”, EKEV Akademi Dergisi, 15 (2003): 159-178.

Çağlayan, Harun. Kelâm'da Bilgi Kaynakları. Doktora Tezi, Ankara Üniversitesi, 2009.

Düzdă̆, M. Ertuğrul. Mehmed Âkif Hakında Araştırmalar II. İstanbul: İFAV Yayınları, 2006.

Edib, Eşref, Mehmed Âkif Hayatı Eserleri ve Yetmiş Muharririn Yazıları. Haz. Fahrettin Gün. İstanbul: Beyan Yayınları, 2011.

Elmalılı, Muhammed Hamdi Yazır. Hak Dini Kur'ân Dili. İstanbul: Eser Neşriyat, 1979.

Ersoy, Mehmed Âkif. Safahat nşr. Ertuğrul Düzdağ, (İstanbul: İz Yayıncılık, 2009.

Ersoy, Tefsîr Yazıları ve Vaazlar, nşr. Ertuğrul Düzdağ, (Ankara: Diyanet İşleri Başkanlığı Yayınları, 2012)

Güven, Şahin. "Kur’âniyyûn Ekolü -Temsilcileri, Tefsirleri ve Tefsirdeki Yöntemi”, Erciyes Üniversitesi Sosyal Bilimler Enstitüsü Dergisi, 11 (2001): 385-408.

Halidî, Salâh Abdülfettah. et-Tefsîru'l-mevżû̀ beyne'n-naz ariyyeti ve't-tațbîk Amman: Dârü'n-Nefâis, 2015/1436.

İbn ‘Atıyye, Ebû Muhammed Abdulahk b. Gâlib b. Abdirrahman. el-Muharraru'l-Vecîz. fî Tefsîri'l-Kitâbi'l-'Azîz, thk. Abdusselam b. Abdişşâfî̀ Muhammed Beyrut: Dâru'lKütübi'l-'Illmiyye, 1422/2002.

İbn Kesîr, Ebû'l-Fidâ İsmail b. Ömer. Tefsîru'l-Kur'âni'l-Azîm, thk. Sâmî b. Muhammed Selâme Riyâd: Dâru Tayyibe, 1420/1999.

İsfehânî, Râğıb. el-Müfredât fì garîbi 'l-Kur'ân. İstanbul: Kahraman Yayınları, 1986. 
Karaman, Hayrettin- Çağrıcı, Mustafa- Dönmez, İbrahim Kafi- Gümüş, Sadrettin. Kur'ân Yolu. Ankara: DİB Yayınları, 2004.

Mâtürîdî, Ebû Mansûr Muhammed. Kitâbu't-tevhid. Nşr. Bekir Topaloğlu, Muhammed Aruçi. Ankara: İsam Yayınları, 2003.

Mâtürîdî, Ebû Mansûr Muhammed. Te'vilâtu Ehl-i Sunne. Thk. Mecdî Bâsellûm. Beyrut: Dâru'l-Kutubi'l-ílmiyye, 2005.

Mehmet Akif Ersoy Yılı Etkinlikleri. "T.C. Kültür ve Turizm Bakanlığı”. Erişim: 6 Ağustos 2019, https://www. aregem.kulturturizm.gov.tr/TR-12228/mehmet-akif-ersoyyili-etkinlikleri.

Münavî, Zeynüddin Muhammed Abdürrauf b. Tacilarifin b. Ali. Feyzü'l-kadîr şerhi'lCâmii's-sağîr. Thk. Hamdî ed-Demirdaş Muhammed. Mekke: Mektebetü Nizâr Mustafa el-Bâz, 1418/1998.

Muttakî, Alî b. Husâmiddîn b. Abdulmelik b. Kadîhân el-Hindî. Kenzu'l-ummâl fî suneni'l-akvvâl ve'l-ef'âl. Nşr. Bekri Hayyani-Saffet Sakka. Beyrut: Muessesetu'rRisâle, 1985/1405.

Nîsâbûrî, Ebû Abdullah İbnü'l-Beyyi' Muhammed Hakim. el-Müstedrek 'ale'sSahîhayn. Thk. Mustafa Abdülkadir Ata. Beyrut: Dârü'l-Kütübi'l-İlmiyye, 1411/1990.

Râzi, Fahrüddin. Mefâtîhu'l-Gayb. Beyrut: Dâru İhyâi Türâsi'l-Arabi, 1420/1999.

Sabûnî, Muhammed Ali. Safvetü't-Tefâsîr. el-Kâhire: Dâru's-Sâbûnî, 1417/1997.

Sarıçam, İbrahim. Hz. Muhammed ve Evrensel Mesajı, (Ankara: Diyanet İşleri Başkanlığı, 2002.

Şen, Ercan. “Âkif Literatürüne Yeni Bir Katkı: Mehmet Âkif Ersoy’un Kur'ân Anlayışına Dair Yapılan Çalışmalar Üzerine Bibliyografik Bir Deneme". FSM İlmi Araştırmalar İnsan ve Toplum Bilimleri Dergisi, 6 (2015): 211-221.

Taberî, Ebû Ali Eminüddin Fazl b. Hasan b. Fazl. Mecmau'l-beyân fî tefsîri'l-Kur'ân, nşr. Haşim er-Resüli Mahallati, Fazlullah el-Yezdi et-Tabatabai. Beyrut: Dârü'lMa'rife, 1406/1986.

Zemahşerî, Ebû'l-Kâsım Mahmûd b. Ömer b. Ahmed. el-Keşşâf an hakâîku gavâmidi'ttenzîl ve uyûni'l-akâvîl fî̀ vucûhi't-te'vîl. Beyrut: Dâru'l-Kütübi'l-Arabî, 1407/1986. 